\title{
Sustainable Poverty Reduction in Less-favoured Areas: Problems, Options and Strategies
}

\author{
Ruerd Ruben, ${ }^{1}$ John Pender ${ }^{2}$ and Arie Kuyvenhoven ${ }^{3}$ \\ ${ }^{1}$ Centre for International Development Issues Nijmegen (CIDIN), Radboud \\ University Nijmegen, PO Box 9104, 6500 HE Nijmegen, The Netherlands; \\ e-mail: R.Ruben@maw.ru.nl; ${ }^{2}$ International Food Policy Research Institute \\ (IFPRI), 2033 K St NW, Washington, DC, USA; e-mail: j.pender@cgiar.org; \\ ${ }^{3}$ Development Economics Group, Wageningen University, Hollandseweg 1, \\ 6706 KN Wageningen, The Netherlands; \\ e-mail: arie.kuyvenhoven@wur.nl
}

\section{Introduction}

Poor people living in less-favoured areas (LFAs) represent globally around $40 \%$ of the rural population suffering from chronic poverty. Given the limited agricultural potential and difficult access conditions in these areas, standard devices for enhancing rural development cannot appropriately address issues of poverty alleviation and sustainable natural resource management. Escaping from the downward spiral of poverty and resource degradation requires the identification of suitable pathways enabling rural households to develop production systems and livelihoods that respond to local conditions (Pender et al., 2001a, b; Pender, 2004; Hazell et al., 2006).

The diversity in agroecological settings and the heterogeneity amongst rural households pose particular challenges to rural development. Instead of a one-size-fits-all strategy, a far more targeted approach is required to exploit the comparative advantage of different resource management strategies for particular types of households and communities (Ruben and Pender, 2004). Moreover, attention needs to be paid to the incentives and governance regimes that enable farmers to adjust their production systems and livelihoods in order to guarantee both welfare and sustainability objectives. Identifying the right combination of public and private investment efforts oriented towards sustainable intensification of farming systems and rural livelihoods is of fundamental importance for attaining such win-win options. 
The chapters included in this book provide an overview of research conducted within the framework of the collaborative research programme on 'Regional Food Security Policies for Natural Resource Management and Sustainable Economies' (RESPONSE). This programme has been jointly managed by the Graduate Schools for Social Sciences and Production Ecology and Resource Conservation of Wageningen University, The Netherlands, in cooperation with the International Food Policy Research Institute (IFPRI), Washington, DC, USA. The programme aimed to identify strategic options for agricultural and rural development in less-favoured areas and policy instruments that enhance rural households' investments in improved and sustainable natural resource management. Fieldwork is conducted in different LFA settings in Eastern Africa (Ethiopia, Kenya and Uganda) and South-east Asia (Bangladesh, Philippines and China) in cooperation with local partner institutes.

Development pathways for less-favoured areas demand careful adjustment of resource use strategies at field, farm-household and village level, looking for a portfolio of activities and technologies that guarantee food security and input efficiency. Given the asymmetric market access, due attention should also be given to options for reducing income inequality and resource degradation and potential pathways for escaping spatial poverty traps. Targeting of incentives towards resource-poor households may be required to guarantee both higher factor returns and improved land management. Therefore, institutional strategies for reducing transaction costs tend to be critically important for enhancing investments and enabling income diversification.

The remainder of this chapter is devoted to a discussion of: (i) the strategic interactions between natural resource management options; (ii) farm-household livelihood strategies for welfare and risk; and (iii) the surrounding market and institutional conditions for simultaneously enabling poverty reduction and sustainable land use. We start with a definition of the main characteristics of LFAs, followed by an analysis of the interactions between poverty and resource degradation in LFAs. Hereafter, the biophysical, micro- and macroeconomic dimensions of LFA development are discussed in order to provide insight in the complex interfaces between agroecological options, household drivers for change and effective incentives for resource use adjustment. We conclude with some major implications for policy and research concerning strategies for sustainable poverty reduction in less-favoured areas.

\section{What are Less-favoured Areas?}

LFAs are usually defined in terms of fragile agricultural resource base and/or limited access. An additional dimension for characterizing LFAs refers to the population dynamics. Contrary to common expectations, 
some LFAs - especially upland areas - have high population densities. This may be caused by historical migration (highlands as a refuge area free of malaria and other diseases and pests) or by socio-economic reasons (smallholder expulsion towards hillsides due to limited access to secure land). In addition, permanent or temporary migration of family members to other areas leads to an unbalanced population structure, characterized by high dependency rates. This is further reinforced by the decline in mortality that precedes the decline in fertility (Lipton, 2005). The demographic transition foreseen for many developing countries is likely to be delayed in LFAs.

Based on the FAO/World Bank classification of farming systems (Dixon et al., 2001) and associated demographic and ecosystems data (Wood et al., 1999), LFAs account for some 1.2 billion (42\%) of the total 3 billion people living in the developing world. Poverty affects globally around 1.2 billion people, $75 \%$ of them living in rural areas. Of these 900 million rural poor, about 360 million live in LFAs. This is equivalent to $30 \%$ of the global poor and $40 \%$ of the total rural poor living in developing countries (see Fig. 1.1). This population is mostly concentrated in the highlands and drylands of Asia and sub-Saharan Africa, although there are substantial numbers of poor people also in LFAs of Latin America (especially in the Andes Mountains and the hillsides of Central America).

Many disadvantaged social groups are concentrated in LFAs (Cleaver and Schreiber, 1994; Bird et al., 2002). These include: (i) women and female-headed households facing unequal opportunities for access to land, education, employment and asset ownership, while male migration results in the feminization of agriculture and a further increase in women's work burden; (ii) landless farmers that depend heavily on

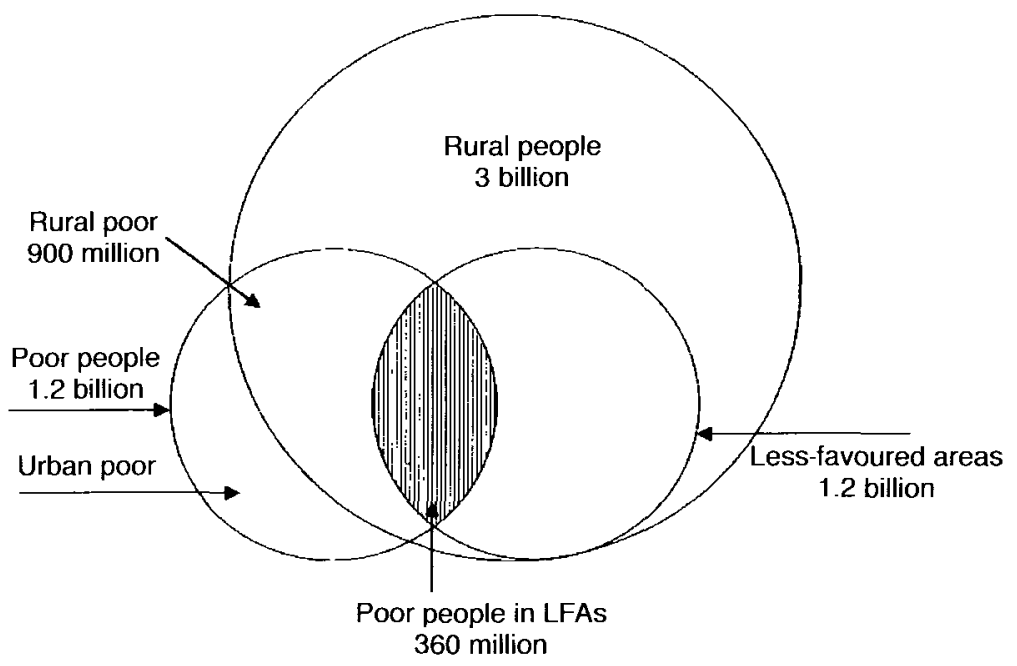

Fig. 1.1. Distribution of poor people in the developing world (from Ruben ef al., 2003). 
poorly remunerated seasonal employment and temporary lease and sharecropping contracts; (iii) indigenous people who have lost their traditional land rights due to the encroachment by migrants in forest areas; (iv) forest dwellers in mountain areas who have become deprived of rights of collection; and (v) fisheries communities that derive their livelihood from capture fisheries along the coastal strips (mostly combined with cropping and off-farm activities) and are threatened by over-exploitation of fishing grounds due to increasing population pressure, undefined property rights and competition from commercial fishing. ${ }^{1}$

For all these reasons, LFAs are a significant part of the human development challenge facing the world community. In addition, they are also a significant part of the global environmental challenge. Land degradation concentrates in LFAs, accounting for about $40 \%$ of the total agricultural area in developing countries, including most of the areas with fragile soils. Soil erosion due to deforestation and reduced fallow periods affects some $20 \%$ of the total land area in developing countries and is heavily concentrated in LFAs. Population pressure, land fragmentation and limited access to inputs all lead to declining yields, and remoteness and the lack of services further aggravate poverty.

Deforestation is occasioning every year 14-15 million ha of forest cover loss in developing countries. Subsistence farming in LFAs is by far the most important driving factor, accounting for about $60 \%$ of total deforestation (FAO, 1997). Soil fertility mining is endemic in many LFAs, especially in areas with poor infrastructure and market access. Rainfed systems suffer from water stress and soil erosion, overgrazing and soil compaction. Agricultural production and yields are low due to very limited use of inorganic fertilizers, erratic rainfall and seasonal moisture stress. In addition, migratory livestock keeping is causing major property rights conflicts. Finally, biodiversity loss - both rare crops and traditional landraces - is loss occasioned by the expansion of traditional cropping, grazing and fuelwood collection into forests, wetlands, parks and other environmentally valued sites.

\section{Poverty in LFAs}

Most studies of rural poverty agree that, globally, there are larger numbers of poor people living in more favourable environments, simply because more people live in such environments (Ryan and Spencer, 2001; TAC, 2001; FAO, 2002). These global estimates are supported by country-level data from Kelley and Parthasarathy Rao (1995) in India, Renkow (1993) in Pakistan and Reardon et al. (1992) in the West African semi-arid tropics, where the absolute numbers of poor were greater in high-potential rainfed and irrigated areas.

However, there is debate about whether the incidence and severity of poverty is greater in LFAs than in more favourable environments 
(Renkow, 2000; Fan and Chan-Kang, 2004). Evidence is limited on the spatial distribution of poverty in most countries, although the evidence available indicates that, in many cases, poverty is more prevalent and severe in LFAs, though this is not universal (Kelley and Byerlee, 2003).

In China, the incidence of poverty is far greater in the low-potential remote upland areas than in the coastal region (IFAD, 2002). Almost all of the 65 million people officially recognized as income-poor in the late 1990s lived in remote and mountainous rural areas (UNDP, 1997). Although the proportion of households below the national poverty line is less than $1 \%$ in the urban areas of Beijing, Shanghai, Tianjin and Guangdong, it is $20 \%$ or more in Inner Mongolia and Qinghai (De Haan and Lipton, 1998). One study found that more than $60 \%$ of the rural poor live in low-potential areas, and that the share of the national total living in such areas has increased since 1986 (Fan et al., 2002).

Several studies in South-east Asia found poverty to be greater in LFAs, but also that other factors are important. For Vietnam, a household survey in the early 1990 s showed that poverty was concentrated in the northern uplands and in the northern part of the central highlands, hilly areas that are far from large cities and the coast and having large ethnic minority populations (Minot, 2000). Although poverty declined rapidly between 1993 and 2002 throughout Vietnam, poverty remains highest in the north-west and central highlands (Swinkels and Turk, 2004).

There is wide variation in poverty rates within poor provinces. For example, in the northern uplands region, poverty rates range from $6 \%$ in Quang Ninh to nearly $80 \%$ in Lai Chau. The incidence and depth of poverty is greatest among ethnic minorities in Vietnam (their poverty rate was nearly $70 \%$ in 2002) (Swinkels and Turk, 2004). Other key factors contributing to poverty in these upland regions are: (i) small farm size; (ii) dependence on forest land and consequent land tenure insecurity; (iii) low education levels; (iv) limited access to health care; and (v) low public spending on investments and services in these areas (Swinkels and Turk, 2004).

In Indonesia, there is a high concentration of poverty in Java, particularly in the limestone hills of Central and East Java (IFAD, 2002). Poverty is also extremely prevalent on Madura in areas far from urban centres, and in fishing villages along the coasts of West and East Java (IFAD, 2002). In the Philippines, the incidence of poverty is $61 \%$ in the uplands compared with $50 \%$ in the lowlands (IFAD, 2002). In a study of poverty and environment linkages in Cambodia and Lao People's Democratic Republic, Dasgupta et al. (2003) found a positive association (correlation $=0.30$ ) between poverty incidence and areas with steep slopes across provinces in Laos, with high incidence of poverty - 
especially in the northern upland region. In Cambodia, by contrast, poverty is concentrated more in flatter lowland areas (Dasgupta et al., 2003).

In South Asia, the relationship is more mixed. For India, Fan et al. (2003) found that the rural poor were increasingly concentrated in rainfed areas, with a relatively equal proportion in high- versus lowpotential rainfed areas. There is a high degree of variability in the incidence of rural poverty across states in India, ranging from $15 \%$ in Punjab to $66 \%$ in Bihar in 1993/1994 (IFAD, 1999). There is also substantial variation within states. For example, in Maharashtra poverty incidence ranges between 24 and $38 \%$ in the coastal and western regions to $62-66 \%$ in the northern and eastern regions (IFAD, 1999). In the Himalayan belt, the largest increase in poverty between 1987/1988 and 1993/1994 occurred in West Bengal, followed by Assam Hills, Arunachel Pradesh and Manipur (IFAD, 1999). Most of these areas are dependent on rainfed agriculture, some have suffered from political unrest and many contain a large number of ethnic minorities. These findings indicate the importance of social and political as well as geographic factors in determining poverty in India.

In Pakistan, the incidence of food poverty in 1990/1991 was highest in rural areas of the South Punjab region, in contrast to low poverty rates in the neighbouring Punjab region of India (IFAD, 2002). The high level of poverty in the Punjab region of Pakistan is attributable to highly unequal access to land, indicating that poverty is affected by other factors besides agricultural potential and access to markets and infrastructure.

Recent poverty mapping work in Bangladesh found that the pockets of high poverty coincided with ecologically poor areas, including the low-lying depression area in the north-east, the drought-prone area on higher land in the north-west, several subdistricts on the fringes of major rivers and several of the south-eastern subdistricts, including the Chittagong Hill Tract (Kam et al., 2005). Despite the importance of some agro-ecological conditions in explaining poverty in Bangladesh (especially the prevalence of highland, low or very low-lying land and heavy soils), socio-economic factors - especially education, but also including access to infrastructure (roads, irrigation and electricity) and landlessness are the strongest predictors of poverty (Kam et al., 2005).

\section{Africa}

Several studies have also shown greater incidence and severity of poverty in LFAs of Africa. For example, the incidence of poverty is much greater in northern Uganda than in the rest of the country, where access to markets, infrastructure and biophysical conditions are more favourable (UBOS, 2003). Besides these geographic factors, however, insecurity and political marginalization are important reasons for poor performance in the northern region (Zhang, 2004). 
In Kenya, income per capita is much higher in the central highlands, with their favourable agroclimatic conditions and access to the Nairobi market, than in the western highlands, which are more remote (Place et al., 2006b). Household wealth (proxied by houses with a metal roof) is significantly greater in rural areas of Kenya having higher rainfall or closer to an urban area (Place et al., 2006a).

In the northern Ethiopian highlands, changes in average wealth, food availability and ability to cope with drought during the 1990 s were more negative in areas further from towns, in more densely populated rural areas and at higher elevations, while more favourable outcomes occurred in communities where road access had improved and where perennial production was important (Pender et al., 2001a, c). Within the lessfavoured northern Ethiopian region of Tigray, however, differences in household endowments of human, social and physical capital were found to be more significant determinants of household income per capita than were geographic factors such as average rainfall or access to markets (Pender and Gebremedhin, 2006; Tesfay et al., Chapter 7, this volume).

\section{Latin America}

In Latin America, some studies also show greater poverty in LFAs. In the southern Andes region, rural poverty is significantly greater in the mountains than in other regions of the same countries (Walker et al., 2000). ${ }^{2}$ In Peru, for example, the incidence of rural poverty (using the nationally defined poverty level) averages about $80 \%$ in the lessfavoured Sierra and Selva regions compared with less than $60 \%$ in the coastal region, while rates of chronic malnutrition are more than twice as high in the Sierra as in the coastal region (Escobal and Valdivia, 2005).

In Honduras, $92 \%$ of households in hillside areas (studied by Jansen et al., Chapter 6, this volume) were found to be extremely poor (with income per capita < US\$1/day) compared with the national rate of extreme poverty of $60 \%$ for all rural households. Within hillside areas, dependence on subsistence basic grains production, which is the livelihood strategy with the lowest income per capita, is greater in areas having lower rainfall, poorer road access and higher population density (Pender et al., 2001b; Chapter 6, this volume). Controlling for livelihood strategies, differences in rainfall and market/road access have limited impact on incomes, and other factors - including soil fertility, ownership of physical assets and participation in agricultural training programmes - are more important determinants of income (Jansen et al., 2006).

These results demonstrate not only that poverty is often more common and more severe in LFAs than in more favoured areas, but also that the social and political context and household level factors such as ethnicity, human, physical and social capital also have very important 
impacts on poverty. Hence, there is great diversity in the incidence and severity of poverty within LFAs, and strategies to address poverty in these areas must therefore be adequately targeted, taking this heterogeneity into account (Ruben and Pender, 2004).

\section{Natural Resource Degradation in LFAs}

Degradation of natural resources is a severe constraint to LFA development. Major problems include the folowing: (i) deforestation; (ii) soil degradation; (iii) increasing water scarcity and resulting declines in natural capital stocks and agricultural productivity; (iv) increasing poverty and vulnerability; and ( $v$ ) environmental damage (losses of biodiversity, reduction in carbon sequestration in soils and plant biomass, sedimentation of rivers and reservoirs, flooding and other environmental impacts).

Land degradation in drylands ${ }^{3}$ (or 'desertification', as defined by the United Nations Convention to Combat Desertification (UNCCD)) and in sloping highlands is a particularly severe problem in LFAs. According to the widely cited Global Assessment of Soil Degradation (GLASOD) study (Oldeman et al., 1991), which used expert judgement to assess the extent and severity of soil degradation globally between 1945 and $1990,14 \%$ of all used land globally was seriously degraded ${ }^{4}$ during this period, but the incidence of degradation was substantially higher in Central America (31\% of used land), Africa $(19 \%)$ and Asia $(16 \%)$ (Oldeeman et al., $1991)$.

Soil erosion by water or wind was the major source of this degradation, causing serious degradation of $25 \%$ of used land in Central America, $16 \%$ in Africa and $15 \%$ in Asia. Other forms of soil degradation, including chemical degradation (soil nutrient depletion, salinization, acidification and pollution) and physical degradation (compaction, sealing and crusting, waterlogging and loss of organic matter) were estimated to affect substantially smaller areas in all regions, including light as well as serious degradation ( $6 \%$ in Central America, $5 \%$ in Africa and South America and $3 \%$ in Asia).

The results of the GLASOD study did not focus on specific agroecological zones, but there are good reasons to expect that the incidence and severity of soil degradation was substantially higher in the drylands and sloping highlands of Africa, Asia and Latin America than was estimated for these continents as a whole. Given the lack of vegetative cover during periods of high rainfall and high winds in drylands, and the steep slopes in many highlands, water and wind erosion are generally much more severe in these regions than in other regions.

A comprehensive study of land degradation in drylands by Dregne and Chou (1992) found even higher incidence of land degradation in drylands, estimating that more than $70 \%$ of drylands in Africa, Asia and Latin America were degraded, including $73 \%$ of rangelands, $47 \%$ of 
rainfed croplands and $30 \%$ of irrigated croplands. That study estimated that more than one-third of irrigated land in Asia and more than one-half of rainfed land in Africa and Asia had experienced at least a $10 \%$ loss in productive potential due to land degradation, and that over one-half of the rangelands in these regions had experienced more than $50 \%$ loss in potential productivity. Based on Dregne and Chou's estimates, Crosson (1995) estimated an average loss (weighted by value of production) for the three land uses to be about $12 \%$, though the loss was much higher for rangelands ( $43 \%$ ) than for irrigated or rainfed cropland.

Numerous studies have assessed soil degradation in specific regions or countries. In a study of soil degradation in South and South-east Asia that replicated the methodology of Oldeman et al. (1991), but using more detailed data, Van Lynden and Oldeman (1997) found that the problems of soil nutrient and organic matter depletion, salinization and waterlogging were much greater than estimated in the global assessment, though they still concluded that soil erosion was the most widespread source of degradation. They estimated that agricultural activity had caused degradation of $27 \%$ of all land in the region, while deforestation had affected $11 \%$ and overgrazing played a minor role.

Studies in China have estimated significant negative effects of land degradation (mainly erosion in sloping areas) on crop productivity, estimating that erosion reduced rice yield growth by $12 \%$ during the late 1980s and early 1990s, and reduced production of maize, wheat and cash crops by up to $20 \%$ in north China (Huang and Rozelle, 1994, 1996). For India, Sehgal and Abrol (1994) synthesized available soil survey data and concluded that more than one-half of the land was suffering from moderate to severe degradation (most of this in less favoured areas) and, on $5 \%$ of the land, degradation was so severe that the soils were unusable.

In Africa, Dregne (1990) found compelling evidence of serious land degradation problems (productivity losses of at least $20 \%$ ) in subregions of 13 countries. Lal (1995) estimated erosion rates for the continent and found that about one-quarter of the land was affected by moderate to severe erosion (particularly in the highlands), estimating that the average crop yield loss in 1989 due to past erosion in Africa was about 8\%, reducing annual cereal production by about 8 million tons, root and tuber production by 9 million tons and pulse production by 0.6 million tons.

Many studies have found evidence of high soil erosion levels and impacts in particular African countries, with most focusing on highland areas in eastern and southern Africa or dryland areas in southern or western Africa (FAO, 1986; Stocking, 1986; Hurni, 1988; World Bank, 1988, 1992; Bishop and Allen, 1989; Convery and Tutu, 1990; Ehui et al., 1990; Bojö, 1991, 1996; Norse and Saigal, 1992; Pagiola, 1993; Sutcliffe, 1993; Grohs, 1994; McKenzie, 1994; Bishop, 1995; Bojö and Cassells, 1995; Eaton, 1996; Sonneveld, 2002). The on-site immediate productivity costs of erosion estimated by these studies vary widely, from less 
than $1 \%$ to as high as $55 \%$ of agricultural GDP, though in most studies estimated annual losses were less than 10\% (Bojö, 1996; Enters, 1998; Scherr, 1999a; Yesuf et al., 2005).

Several studies have also estimated rates of soil nutrient depletion in Africa. Stoorvogel et al. (1993) estimated average annual nutrient losses in Africa of $22 \mathrm{~kg} /$ ha of nitrogen $(\mathrm{N}), 2.5 \mathrm{~kg} / \mathrm{ha}$ of phosphorus (P), and 15 $\mathrm{kg} / \mathrm{ha}$ of potassium (K); and much higher rates of depletion in the densely populated and erosion-prone countries of eastern and southern Africa (especially Ethiopia, Kenya, Malawi and Rwanda).

High rates of soil nutrient depletion have also been found by numerous studies conducled at lower scales in several African countries, most of these also in highland or dryland areas (e.g. Van der Pol, 1992; Smaling et al., 1997; Baijukya and De Steenhuijsen Piters, 1998; Bationo et al., 1998; Defoer et al., 1998; De Jager et al., 1998, 2004; Elias et al., 1998; Folmer et al., 1998; Shepherd and Soule, 1998; Van den Bosch et al., 1998; Wortmann and Kaizzi, 1998; Gitari et al., 1999; Onduru et al., 2001; Gachimbi et al., 2002, 2005; Woelcke, 2003; Nkonya et al., 2004. 2005a; Abegaz, 2005), although high rates of nutrient depletion are not universal (Muchena et al., 2005).

Few studies have quantified the productivity impacts of soil nutrient depletion in Africa. A long-term experimental trial in Kabete, Kenya, of 18 years of continuous maize production in absence of nutrient inputs, showed a decline of maize yields from 3 to 1 ton/ha (Bekunda et al., 1997). Other long-term experimental studies in sub-Saharan Africa show that, under continuous cultivation using low external inputs, soil fertility rapidly decreases and yields decline, and that a combination of inorganic and organic sources of soil fertility is necessary to sustain crop production (Juo and Kang, 1989; Vlek, 1990; Swift et al., 1994; Bationo et al., 1998). A few recent studies estimated the replacement costs of lost nutrients as averaging about one-fifth of farm income in several districts of Uganda (Nkonya et al., 2005a, b) and one-third of farm income in three Kenyan districts (De Jager et al., 1998).

Many of the studies of land degradation in Africa and elsewhere are based on expert opinion (e.g. Oldeman et al., 1991) or on assumptions and relatively few plot-level trials (Stoorvogel et al., 1993). However, recent advances in remote sensing and ground survey methods have substantiated the existence of significant land degradation at landscape scale. For example, use of near infrared spectrometry to assess soil quality and land degradation over wide areas has been able to provide evidence of the extent of degradation in the Nyando River Basin of Kenya. Cohen et al. (2005a) found that about $56 \%$ of the land was moderately to severely degraded. Further research combining measured soil degradation with estimated effects on crop yields (Cohen et al., $2005 b)$ calculated the costs of soil erosion at the national level in Kenya to be equivalent to $3.8 \%$ of GDP. Evidence from laboratory analysis of changes in soil properties from sample plots in small farmers' fields in Uganda that were resampled 40 years after an earlier soil survey (Ssali, 
2003) also supports the view that soil fertility has declined in East Africa.

For Latin America, Oldeman (1998) estimated that agricultural productivity was 37\% lower in Central America and 14\% lower in South America as a result of soil degradation, based on the results of Oldeman et al. (1991). Lutz et al. (1994) estimated that, over a 10-year period without conservation measures, maize yields would decline in hillsides of Honduras by $20-25 \%$, maize and sorghum yields would decline in Haitian hillsides by $60 \%$, bean yields would decline by $20-25 \%$ in the Dominican Republic, coffee yields would decline by $10 \%$ in the Costa Rican highlands and cocoyam yields would fall to zero in the human lowlands of Costa Rica.

Cuesta (1994) estimated that uncontrolled erosion in Costa Rica would reduce highland coffee yields by one-half within 3 years and to zero within 20 years, highland potato yields by $40 \%$ over 50 years and lowland cocoyam yields by more than one-half in the first year and to zero by the fourth year. Solórzano et al. (1991) estimated the replacement costs of soil nutrients lost annually due to soil erosion in Costa Rica, and estimated this cost to be in the range of 5-13\% of agricultural GDP. For Mexico, McIntire (1994) estimated that soil erosion reduced maize production by an average of about $3 \%$, but with losses as high as $12 \%$ in some states, and losses being especially high in the highlands and semi-arid regions.

Many of these estimates probably overstate the impact and cost of soil erosion, however, since they do not consider farmers' mitigation efforts. For example, Pagiola and Dixon (1997) found that farmers in hillside areas of El Salvador perceived significant erosion problems on most of their sloping fields, but also that severe, long-term productivity declines were expected by farmers on only $16 \%$ of steeply sloping fields and $5 \%$ of moderately sloping fields.

In the past decade, several critics have challenged the generality, methodology, accuracy and motivations of many studies commonly cited in the literature concerning the extent and impacts of land degradation, especially in Africa. Several studies question the extent of land degradation, providing examples of particular cases where land conditions have improved in recent history (Tiffen et al., 1994; Fairhead and Leach, 1996; Leach and Mearns, 1996; McCann, 1999) or evidence that earlier land conditions (e.g. forest cover) were not as favourable as previously thought (McCann, 1999). Some studies argue that land degradation is highly context specific, acknowledging that land degradation is a problem for some farmers in some places and times, but arguing that the problem is not as universal as sometimes claimed.

Some studies critique the methods used by agronomists and others to estimate land degradation as being conceptually flawed, subject to large errors and driven by political motives (e.g. Stocking, 1996; Bassett and Crummey, 2003; Keeley and Scoones, 2003; Fairhead and Scoones, 2005). For example, the common practice of scaling-up estimates of soil erosion based on plot level measurements and models to larger national 
or regional scales may overstate the impacts of erosion by orders of magnitude, since most of the soil eroded from particular plots is redeposited in nearby fields (Stocking, 1996). Several studies deconstruct and critique the 'Malthusian narrative', which predicts that land degradation is the inevitable result of population pressure and poverty and suggests that drastic action by governments is required to address it (Hoben, 1995; Leach and Mearns, 1996; Bassett and Crummey, 2003; Keeley and Scoones, 2003). Most of the authors in this tradition argue that greater appreciation of farmers' knowledge and ability to adapt and innovate is needed, as well as greater understanding of the local historical, political and sociocultural context.

Some of these criticisms are well-founded (Koning and Smaling, 2005). Land degradation is certainly not an inevitable consequence of population growth or of poverty, the relationships among these and other factors are complex and context dependent, and there are many examples of sound land management practices being practiced by small farmers in many developing countries. Nevertheless, there are many studies that document serious degradation, and some of the studies questioning the importance of land degradation also suffer from methodological flaws, such as ignoring sources of soil nutrient outflows that are difficult to quantify (Koning and Smaling, 2005).

Much of the evidence on land degradation is synthesized in the recently completed Millennium Ecosystem Assessment (MEA, 2005). The preponderance of evidence supports the view that land degradation is indeed a very serious problem, especially in the less-favoured drylands and highlands of Africa, Asia and Latin America.

\section{Heterogeneous Resources and Mixed Farming Systems}

Less-favoured areas have gained little from past agricultural successes and suffer widespread poverty and resource degradation. They include lands that are of low agricultural potential due to limited and uncertain rainfall, poor soils, steep slopes or other biophysical constraints, as well as areas that may have higher agricultural potential but which are presently under-exploited due to limited access to infrastructure and markets, low population density or other socio-economic constraints. Most LFAs are mountain regions ('uplands', see Jansen et al., Chapter 6, this volume) or arid and semi-arid zones ('drylands', see Assefa and Van Keulen, Chapter 5, this volume).

They can be defined more fully on the basis of the predominant farming systems. Table 1.1 outlines the six major farming systems that encompass most of the LFAs in developing countries. These systems are defined according to resource use regimes (CGIAR/TAC, 2000) and to a recent assessment of poverty incidence in tropical farming systems by FAO/World Bank (Dixon et al., 2001). These farming systems cluster into dryland and upland farming systems, and together comprise about $40 \%$ 
Table 1.1. Predominant farming systems in less-favoured areas (based on FAO-World Bank, 2001).

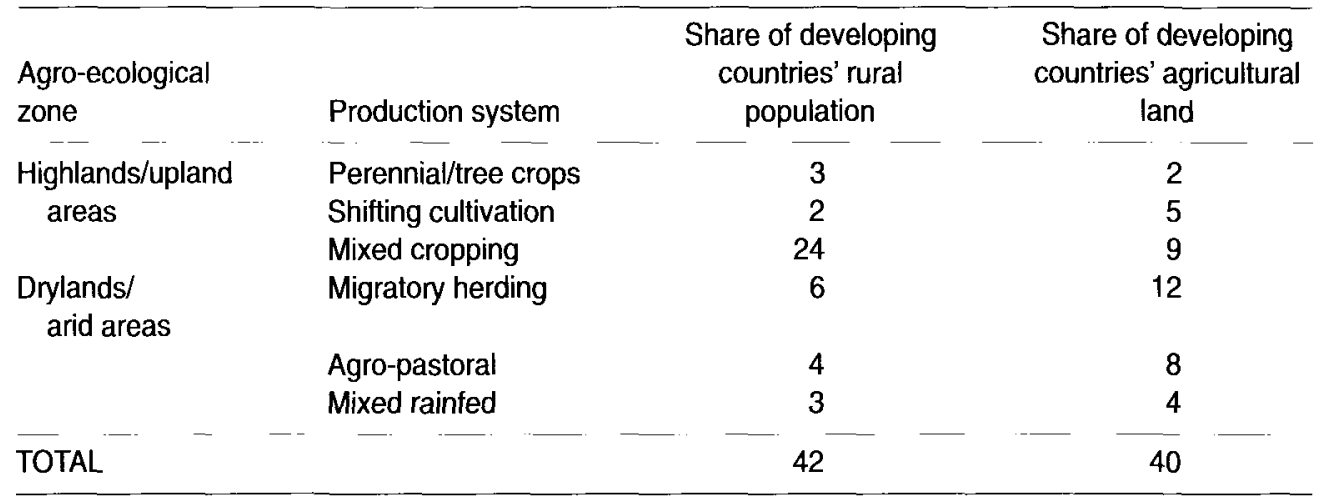

Note: estimates based on FAO expert judgements (Delphi method).

of the agricultural land area and $42 \%$ of the rural population in the developing world.

We discuss the dominant farming systems in LFAs for identifying the available options for reinforcing their productivity and sustainability (see also López-Ridaura et al., Chapter 2, this volume). Development strategies for sustainable resource intensification in LFAs need a careful adjustment of resource use at field, farm-household and village levels, looking for a portfolio of activities and technologies that guarantee input efficiency and labour productivity. Major characteristics and typical constraints of each of these LFA farming systems can be illustrated as follows.

\section{Highlands and upland areas}

\section{Perennial and tree crop systems}

These systems are found in the East African highlands, Central American and Andean hillsides and South-east Asian uplands. They include crops like banana, plantain, coffee, cocoa and multi-purpose trees, interplanted with food crops like cereals and cassava, and combined with small-scale animal husbandry. Cereals, roots and tubers are the main staple, while tree products and off-farm activities provide some cash income. Major limitations are soil fertility, scarcity of good planting material and high establishment and maintenance costs. In many cases, lack of market outlets and insecure property rights constrain agroforestry development. Many indigenous peoples are dependent on these farming systems.

\section{Upland shifting cultivation}

This is found in the forest margins of East and Central Africa and Southeast Asia. It is based on the annual clearing of bush fields for the cultivation 
of food crops (maize, sorghum and cassava) and their subsequent recovery under fallow. The slash-and-burn system is severely threatened by shortened fallow, typically driven by increasing human population and encroachment into forest margins by sedentarized cultivators, occasioning soil erosion and nutrient depletion. Recovery periods become longer and returns to agricultural activities continuously decline. Poverty is further aggravated by remoteness and the absence of service provision.

\section{Mixed cropping system}

Mixed upland cropping systems are found in the semi-humid highland areas of Southern Africa, the South-east Asian uplands and in Central America, and are based on the intercropping of cereals, in rotation with legumes, beans, tubers and pulses. Farmers use animal traction for land preparation and rely on crop residues and mulching for soil fertility management. Upland rice systems increasingly suffer from decreasing water efficiency and salinity problems. Other major constraints are low soil fertility and high seasonal labour demands. Distance is prohibitive for further market integration.

\section{Drylands and (semi-)arid areas}

\section{Migratory herding}

This is found mainly in the arid areas of sub-Saharan Africa, the Middle East, North Africa and Central Asia. It is based on transhumant pastoralism with mixed herds of cattle, camels, sheep and goats that depend on the availability of grass, water and crop residues in neighbouring arable systems. Critical management issues relate to animal health care and scarce feed availability, especially during periodic droughts. Socio-economic differentiation is considerable and many herders lose their stock to drought or theft. Opportunistic grazing by sometimes externally controlled herds leads to conflicts over land and water rights with agricultural communities.

\section{Agro-pastoral systems}

These are found in the semi-arid regions of sub-Saharan Africa, the Middle East, North Africa and South-east Asia. They are based on the integration of cropping and livestock activities. Major components include linear agroforestry arrangements, production of fodder crops, manure recycling and use of animals for land preparation and transport. Sections of the animal herds may seasonally migrate to semi-humid areas. Farmers use early-maturing and drought-resistant crop varieties and grain storage for overcoming the dry period. The system is vulnerable to frequent crop failure, shortage of animal feed, large grain price variations and the periodic collapse of livestock prices. 


\section{Rainfed mixed cropping}

This is found in Central and Southern Africa, South Asia, the coastal part of North Africa, north-east Brazil and the Yucatan peninsula in Mexico. It is based on seasonal cultivation of food and cash crops, using locally available resources. Sorghum, millet, maize and barley are major food crops, providing stubble grazing by animals after the harvest; cattle, sheep and goats provide the major part of cash income. Water shortages and soil fertility decline limit yields. Crop harvests are also seriously affected by weed infestation (Striga). Problems of unequal land distribution and poor market linkages lead to chronic poverty.

\section{Farming systems development in LFAs}

Local experiences with sustainable agricultural intensification offer some promising perspectives for simultaneously improving resource management and generating stable income streams to rural households living in LFAs. We outline six major strategies for pro-poor sustainable intensification in highland and dryland areas, focusing on their potential for adoption by poor farmers in different LFA settings (see Table 1.2). Particular attention is given to the identification of local economic incentives and the knowledge infrastructure that should be in place to facilitate the process of upscaling of sustainable agricultural practices in LFAs.

\section{Agroforestry}

Agroforestry systems supply rural households with a wide range of products for domestic use and sales, including food, fruits, medicine,

Table 1.2. Technology options for LFA production systems intensification (from Hazell et al., 2006).

\begin{tabular}{|c|c|c|c|c|c|c|}
\hline $\begin{array}{l}\text { Farm management } \\
\text { practices }\end{array}$ & $\begin{array}{l}\text { Agro- } \\
\text { forestry }\end{array}$ & $\begin{array}{c}\text { Nutrient } \\
\text { manage- } \\
\text { ment }\end{array}$ & $\begin{array}{c}\text { Plant } \\
\text { protection }\end{array}$ & $\begin{array}{c}\text { Water } \\
\text { manage- } \\
\text { ment }\end{array}$ & $\begin{array}{l}\text { Livestock } \\
\text { and } \\
\text { pastures }\end{array}$ & $\begin{array}{c}\text { Seed } \\
\text { and } \\
\text { biotech }\end{array}$ \\
\hline \multicolumn{7}{|l|}{ Farming systems } \\
\hline \multicolumn{7}{|c|}{ Highland and upland areas } \\
\hline Perennial tree crops & a & & & & & $\mathbf{\square}$ \\
\hline Shifting cultivation & घ & a & घ & & $\boldsymbol{\square}$ & \\
\hline Mixed cropping & & - & घ & घ & - & a \\
\hline \multicolumn{7}{|c|}{ Semi-arid and dryland areas } \\
\hline Migratory herding & & & & & घ & \\
\hline Agro-pastoral & - & & & घ & ш & - \\
\hline Mixed rainfed & & $\mathbf{E}$ & $\mathbf{n}$ & $\mathbf{a}$ & & $\mathbf{\square}$ \\
\hline
\end{tabular}

Source: Hazell et al. (2006) 
feed and fodder, fuelwood and timber, and also provide environmental services, such as erosion control and moisture conservation. Prospects for establishing agroforestry systems are particularly high in fragile hillsides and semi-arid lowlands where the benefits of annual cropping are low and risky (Neupane and Thapa, 2001).

Agroforestry can offer attractive returns to poor farmers. In the Dhading district of Nepal, where planting of multipurpose trees almost doubled net returns to farming at only slightly higher costs, including the additional income from fodder, fuelwood and timber. Short-rotation improved fallow with Sesbania species as green manure crop in densely populated hillside areas of Western Kenya had little effect on cereal yields but led to savings in weeding labour, thus offering farmers options for engagement in off-farm employment (Swinkels and Franzel, 1997). Other benefits from agroforestry systems include the added value from woody and non-timber forest products (NTFPs). For Cameroon, the commercial value of NTFP almost doubles farmers' incomes (Leaky and Tchoundjeu, 2001). Especially women in homestead and community areas frequently manage mixed-tree systems with fruit and woody species.

Soil conservation programmes in dryland areas rely on linear forestry arrangements (windbreaks and shelterbelts), while contour hedgerows are applied on moderate slopes, and agroforestry and mixed trees on steeper slopes. Soil fertility and nutrient uptake in mixed cropping systems benefit greatly from intercropping with leguminous trees. In sub-Saharan Africa, the combination of agroforestry with phosphate rock applications substantially improves nitrogen uptake and crop yields (Sanchez and Jama, 2002). Land reclamation through agroforestry is done with multipurpose trees, fodder shrubs and grasses, usually assisted by biomass transfers and specific soil conservation measures (ridge tillage) on sloping lands. In Tobora district in Tanzania, rotational woodlots assist farmers in generating substantial income while at the same time conserving large forest areas (Ramadhani et al., 2002). Agroforestry contributes to the reduction in the pressure of shifting cultivation and the control of erosion through more permanent land cover.

Agroforestry systems that are particularly interesting to poor farmers in LFAs include those that have low establishment and maintenance costs, face limited competition with other activities and exhibit high synergy effects for enhancing soil fertility and water storage capacity. Moreover, expected returns should become available after a short period, and stable market outlets need to be accessible when a marketable surplus is produced.

Although most agroforestry research has focused on semi-humid hillside regions, tree crops that have a high drought tolerance also represent an interesting component of agro-pastoral development in dryland areas. Trees that enhance synergy with arable or pastoral activities can contribute to both sustainability and profitability of mixed farming 
systems. Current initiatives in agroforestry seek the domestication of trees in order to integrate indigenous species into tropical farming systems (Wiersum, 1997; Leaky and Tchoundjeu, 2001).

Most promising results in agroforestry are reached with fast-growing tree species (Tephrosia, Sesbania) incorporated in improved fallow systems for maize and vegetables (Western Kenya and Eastern Zambia), droughtresistant trees (pistachio, almond) used for soil moisture upgrading and fodder provision in the semi-arid regions of Tunisia, living fences used in the marginal drylands of the Sahel and Central America and contour farming on acid soils in the uplands of the Philippines. Techniques like alley cropping, hedgerow intercropping and community woodlots are less easily adopted by smallholder farmers due to their high labour or input costs.

The adoption of agroforestry technologies typically depends on local resource endowments, the opportunity costs of land and labour, and market and institutional conditions. Where population density is high, fallow periods are decreasing and, when farmers perceive a decline in soil fertility, improved tree fallow has a great potential (Franzel, 1999). In more densely populated areas, forestry is feasible only with rapidly growing varieties and high-value by-products. Adoption of hedgerow technologies has been rather limited because short-term returns are too small and rather uncertain (Nelson et al., 1998). Contour farming with natural vegetative strips - although less effective for reducing soil erosion - can be a better alternative due to its lower establishment costs and reduced maintenance requirements (Garrity, 2002).

\section{Soil nutrient management}

Farmers' soil fertility management practices include a wide variety of agronomic, biological and mechanical measures to reduce soil and water erosion, reinforce soil fertility and soil structure and to safeguard soil biological processes. These measures enhance the availability and efficient uptake of soil nutrients, and reduce water constraints. Strategies for Integrated Nutrient Management (INM) rely on the combination of appropriate organic and inorganic fertilizer applications, soil and water management practices, and agronomic and soil conservation measures to increase yields and maintain the ecosystem stability of the environment (Vanlauwe et al., 2002).

High nutrient deficits are registered in subsistence-oriented rainfed cropping systems that use almost no fertilizers and are located in more remote areas. Agricultural yields in sub-Saharan Africa are severely limited due to very low inorganic fertilizer use (on average only $8 \mathrm{~kg} / \mathrm{ha}$ compared with $107 \mathrm{~kg} / \mathrm{ha}$ in all developing countries). Sustained treatments with only inputs of organic matter (green or animal manure, crop residues) are usually not sufficient to halt declining yields. Soil replenishment with phosphate rock in West Africa could increase crop 
yields by $20-30 \%$ (Diop, 2001). Farmers are somewhat reluctant to use phosphate rock given the high investment costs and detrimental effects on health (Kuyvenhoven et al., 1998).

The impact of soil and water conservation measures on farmers' income varies strongly between different settings. In the Sahelian countries, simple and low-cost technologies (e.g. earth bunds, vegetation strips, windshields) that retain soil nutrients and reduce erosion contribute to slightly higher (and more stable) yields and higher income (De Graaff, 1996; Reij and Steeds, 2003). In Northern Africa and in the East African Highlands regions, land management is more focused on soil and water conservation, and agronomic measures (intercropping, agroforestry) proved to be able to provide win-win solutions with reduced erosion and increased productivity (Shiferaw and Holden, 1999).

On the steep hillsides of the Chiapas region in Mexico, the combination of conservation tillage and crop mulching increased net returns to land and labour by 13 and $28 \%$, respectively (Erenstein, 1999). In the Central American hillsides, average smallholder maize yields were three to nine times higher after a period of 10-22 years relying on cover crops and green manure (velvet beans) as a method for improving soil fertility (Bunch, 2002). Intensive training and support for these programmes has been provided by local NGOs, and diffusion took place through a 'farmer to farmer' methodology. Recent studies point, however, to dis-adoption of green manuring due to plant diseases and difficulties in adapting to changing agroecological conditions.

Population density, rainfall and market orientation influence the scope and feasibility of specific soil fertility measures (Scoones and Toulmin, 1999). Crop diversification, terracing and INM practices are used mainly in high population density highland regions like western Kenya and north-east Nigeria. Grass-strips, contour bunds, composting and manure are applied in more remote locations in the south-west Ethiopian highlands and the central region of Malawi. Mixed farming systems with strong crop-livestock integration become a feasible option in rainfed regions with a regular population density. In the semi-arid regions with lower population densities and variable rainfall, labourextensive silvopastoral and improved fallow systems offer feasible alternatives.

Even within the same region, adoption of soil and water conservation (SWC) measures is unequally distributed amongst households. In Atacora district in north-west Benin, larger farmers with cattle and commercial crops used improved fallow, chemical fertilizer and manure for soil fertility management, while small farmers with more food crops used more labour-intensive crop residue management options to maintain soil fertility (Mulder, 2001). Less-endowed households benefit substantially from programmes for indigenous SWC technologies, like water harvesting (tassa) in Niger, rectangular ridges (sagan) in Nigeria and bench terraces in Togo (Reij et al., 1996). 


\section{Plant protection}

Pests and diseases lead to high crop loss at different stages of the production process. Postharvest losses in farm level storage typically represent $2-8 \%$ of the production weight, while losses in storage and transport are about 3-7\% (Boxall, 2001). In tropical areas, plant diseases and pest infestation strongly limit the harvested output until reaching complete crop failure. Post-harvest losses can be equally large. Pest incidence in LFAs is most relevant in semi-intensive cropping systems that face water stress or nutrient limitations typical for poor farmers, and is best controlled through cultural practices that maintain pests at a controllable level.

Conventional synthetic pesticides tend gradually to lose their effectiveness and concerns are growing regarding the detrimental health and environmental effects. Integrated pest management (IPM) strategies for cereals and cassava crops have been developed that use a combination of biological, cultural, genetic and chemical techniques to maintain pest populations below an economically damaging level (Swinton and Williams, 1998). IPM programmes that reduce pest problems while minimizing environmental damage are potentially winwin strategies.

Plant protection measures by poor farmers in LFAs are mostly based on local techniques. Due to high variability, site-specific pest management techniques are needed. Crop rotation and intercropping are the most commonly used plant protection devices. Labour shortages that lead to low-intensity weeding may increase the vulnerability to pests and diseases. Most recommended IPM strategies for combating pests in maize, beans and pigeon pea in southern Malawi, like inorganic fertilization and weeding for Striga control, and mulching for controlling bean stem maggot, require considerable labour or cash inputs and are thus less accessible to poor farmers. Poor farmers tend to select simple and low-cost IPM methods (Chaves and Riley, 2001), and measures based on varietal resistance, botanical seed dressing, biological control with fungi and trap crops have a large potential for being adopted by resource-poor farmers (Orr and Jere, 1999).

\section{Water management}

Poor farmers in semi-arid areas suffer from water shortages and declining water quality. Competition for water by different stakeholders asks for improved efficiency in water use through appropriate systems for water allocation and management. Participatory planning of resource use at watershed level enables the selection of appropriate water conservation practices and makes significant contributions to agricultural productivity, natural resource conservation and poverty alleviation (Kerr et al., 2001). 
Water-harvesting techniques like small dunes and planting pits (tassa) are widely adopted by smallholders in Niger. Within the framework of the IFAD-funded Soil and Water Conservation Project, within 4 years $46 \%$ of the farmers had applied the new techniques in small areas of 0.9-1.4 ha. Training and extension, and food-for-work rations (in dry years), tools and community infrastructure have supported rapid dissemination (Hassane et al., 2000). Surface drainage with broad-beds and furrows is widely used in the central highlands of Ethiopia to protect crops from waterlogging (Deckers, 2002). Given the climate change projections, rainfall variability in sub-Saharan Africa tends to increase, and cropping periods may become shorter (Dietz et al., 2004). Consequently, demand for micro-irrigation and further improvement of water harvesting strategies is of primary importance (Rosegrant and Perez, 1997).

Small-scale, farmer-controlled irrigation programmes that use simple and low-cost technologies of river diversion, lifting with small (hand or rope-Jpumps from shallow groundwater or rivers, or seasonal flooding, are successful in Africa, Central America and the Andes region. In Zimbabwe, low-cost indigenous water management systems for dambo gardens managed by individual farmers on land allocated by local communities allow flexible water management, based on shallow wells and water channels between beds. Initial investments (US\$500/ha) are four to 20 times lower than for conventional gravity irrigation, while returns are twice as high because high-value horticulture crops are grown instead of grains (Rukuni et al., 1994). Dambo gardens are about ten times more productive than dryland farming, prevent erosion and protect downstream water flows, and can relieve pressure on upland resources. Dambo gardens now cover about 15,000-20,000 ha in Zimbabwe (compared with 150,000 ha of formal irrigation) and there is a potential to develop another 60,000 ha.

Programmes for integrated aquaculture require only limited amounts of land and show highly positive returns, but require access to stable feed sources from animal or chicken manure, garden and kitchen waste. In Malawi, the vegetable-garden-pond system generates annually US $\$ 14 / 100 \mathrm{~m}^{2}$, compared with US\$1-2 for cropping activities (Brummett, 2002). In addition, income from fishponds is more stable and compensates in adverse years for losses in crop income.

\section{Livestock and pasture management}

Livestock production is considered as an attractive device for supporting simultaneously objectives of poverty reduction, food security and environmental sustainability (De Haan et al., 2001). In LFAs, the dual function of livestock as a production and a stock-keeping activity contributes to both income and wealth. The latter function is especially important in parts of sub-Saharan Africa, providing a source of savings 
and a buffer against calamities (Fafchamps et al., 1998). Livestock provides a relative high share of income to the rural poor, including landless farmers (Delgado et al., 1999). Proteins and calories from animal products are a critical supplement to the rural diet. Women play a predominant role in the marketing of livestock products. Given the low labour requirements of livestock keeping, it can be easily combined with other income-generating activities. Moreover, economies of scale are relatively small in primary livestock production, but become more important in processing and marketing.

In LFAs, most widespread constraints to livestock intensification are the availability of feed, forage and fodder from different sources (McIntyre et al., 1992). Fertility and mortality rates, gestation periods and inter-calving periods are influenced by feed intake adequacy, sanitary measures and infrastructure provisions (stalls), and veterinary care activities (Hengsdijk, 2002). Alternatives have been developed to reduce feed and water constraints, based on improved pasture management (area rotation, silvo-pastoral systems), production of leguminous fodder crops and the use of crop residues and industrial sub-products (e.g. feedblocks in Northern Africa, cottonseed in West Africa).

Success has been reached mostly in areas where increasing stocking rates - associated with higher population density and land scarcity - and more commercially oriented livestock production provoke a better delineation of grazing and watering rights. Moreover, in closed settled zones, livestock and crop systems become more integrated and land use intensity, as well as labour input, increases with population densities. Hoffman et al. (2001) found that, in remote areas of north-west Nigeria, indigenous strategies to exchange manure for crop residues with transhuman herders were still effective. Cattle played a key role in nutrient recycling, thus taking advantage of spatial and temporal variability.

In a similar vein, in intensive smallholder systems of upland Java, cattle are permanently maintained in backyards and fed with indigenous forage cut from field margins and roadsides (Tanner et al., 2001). Intensive cropping cycles, high population densities and high livestock densities leave little land for grazing. Although cut-and-carry feeding is labour intensive, it is surprising that farmers collect quantities greatly in excess of the requirements of their livestock. The refused feeds associated with this 'excess feeding' are composted with animal manure for subsequent use on surrounding fields. The compost contributed to increased value by improving soil structure and water-holding capacity, in addition to providing soil nutrients. Poor, landless households participate in the cut-and-carry compost production system and thus gain an important supplementary income.

Direct income effects of livestock development projects tend to be attractive. Farmers participating in the Sichuan livestock development project in China (with 68,000 direct beneficiaries) saw their average net 
income rise by almost $50 \%$. In a similar vein, farmers in the Mahreq and Maghreb programme in the Middle East reduced input costs for feeding by more than $50 \%$. In Indonesia, the IAF/WB Smallholder Cattle Development Programme involved more than 70,000 smallholders in livestock keeping and showed an economic rate of return of $16 \%$ (AfifiAffat, 1998).

Integration of cropping and livestock activities represents in semiarid areas a main strategy for income diversification, asset creation and risk management. Livestock can reinforce arable cropping activities through manure provision and animal traction. Household welfare proved to be strongly dependent on the availability of both animal traction and simple implements for timely land preparation (Berckmoes et al., 1990). Access to better-quality feed and fodder reduces the exclusive reliance on pastures and permits an increase in stocking rates. Public and private financial and extension institutions played a catalytic role in promoting sustainable intensification of mixed and integrated crop-livestock systems in Burkina Faso, Mali and Tanzania (Williams et al., 1999). Subsidized feeding programmes may, however, easily lead to overstocking, and input subsidies artificially impose economies of scale.

\section{Seed, breeding and biotechnology}

The development of agroforestry and tree systems is strongly dependent on the availability of high-quality germoplasm and planting material of appropriate species that permit adequate planting intervals for specific agroecosystems. Agro-pastoral and mixed rainfed cropping systems could greatly benefit from new breeding technologies that increase crop tolerance to drought and extreme temperatures, and improve pests and disease resistance. Conservation tillage greatly benefits from herbicideresistant varieties. Breeding for resistant varieties of maize and beans that are suitable for direct seeding holds potential environmental benefits for developing countries, where these crops are often grown on erosion-prone hillsides in LFAs.

Other prospects for genetically modified (GM) techniques are found in the control of major diseases in livestock, nitrogen fixation in cereals and new types of processed foods, etc. Cross-breeding and selection of native breeds are used as procedures for genetic improvement and gradual upgrading in animal systems, but artificial insemination and imported breeds can be applied to speed up the process. The performance of improved breeds tends to suffer from feeding and management problems, and needs to be accompanied by strong training and extension activities.

GM techniques are an increasingly important part of crop improvement strategies and can be potentially very useful for addressing some location-specific production constraints faced by the poor in marginal areas, for reducing environmental damage as well as for producing more nutritious foods that are of particular importance for 
addressing malnutrition in LFAs. Since it is unlikely that the private sector is willing to invest in research for areas with limited financial resources, higher public investment in agricultural research is needed. The same holds for marker-assisted breeding (not involving gene transfer) in combination with Information and Communication Technology (ICT), offering substantial promises for speeding up on-farm participatory breeding to evaluate the potential of different varieties for LFAs.

Biotechnology also brings new risks and problems. Most current agricultural biotechnology research is being undertaken by multinational companies and caters to the problems of rich farmers and developedcountry consumers. Few outputs from this research will be appropriate for farmers in LFAs. Crop varieties with built-in herbicide resistance require much greater reliance on herbicides than is common in developing countries, where most weeding is still done by hand. Crop varieties that incorporate $B t$ genes for insect pest resistance need to be surrounded by refuge areas of non- $B t$ varieties if insects are not to become resistant. This may be hard to enforce in most developing countries. Biotechnology might also bring environmental risks associated with the release of genetically modified material (e.g. gene jumping, new pests) and from the consumption of genetically modified foods (e.g. allergic: reactions, toxins). These risks are not yet fully understood and provoke a great deal of anxiety among some segments of the public. National institutions must have the capacity to evaluate these risks, and to implement and rigorously enforce appropriate regulatory systems for biosafety (Ruben et al., 2003).

\section{Livelihood Strategies and Development Pathways in LFAs}

In recent years, development practitioners and researchers have emphasized the need to take into account the diverse set of activities that individuals, households and communities undertake to sustain and improve their livelihoods, and the underlying driving and conditioning factors that promote or hinder livelihood improvement, in order to more effectively address rural poverty, food insecurity and natural resource degradation in developing countries (see Brons et al., Chapter 3, this volume).

The sustainable livelihoods framework (SLF), promoted by the Department for International Development of the United Kingdom (DFID), emphasizes the role of the vulnerability context and household assets (broadly defined to include physical, human, natural, social and financial assets) in determining the livelihood strategies of individuals and households (Ashley and Carney, 1999; DFID, 1999; see Fig. 1.2). In the SLF, livelihood strategies are defined as the range and combination of activities and choices that people make/undertake in order to achieve their livelihood goals (including productive activities, investment strategies, reproductive choices, etc.). 


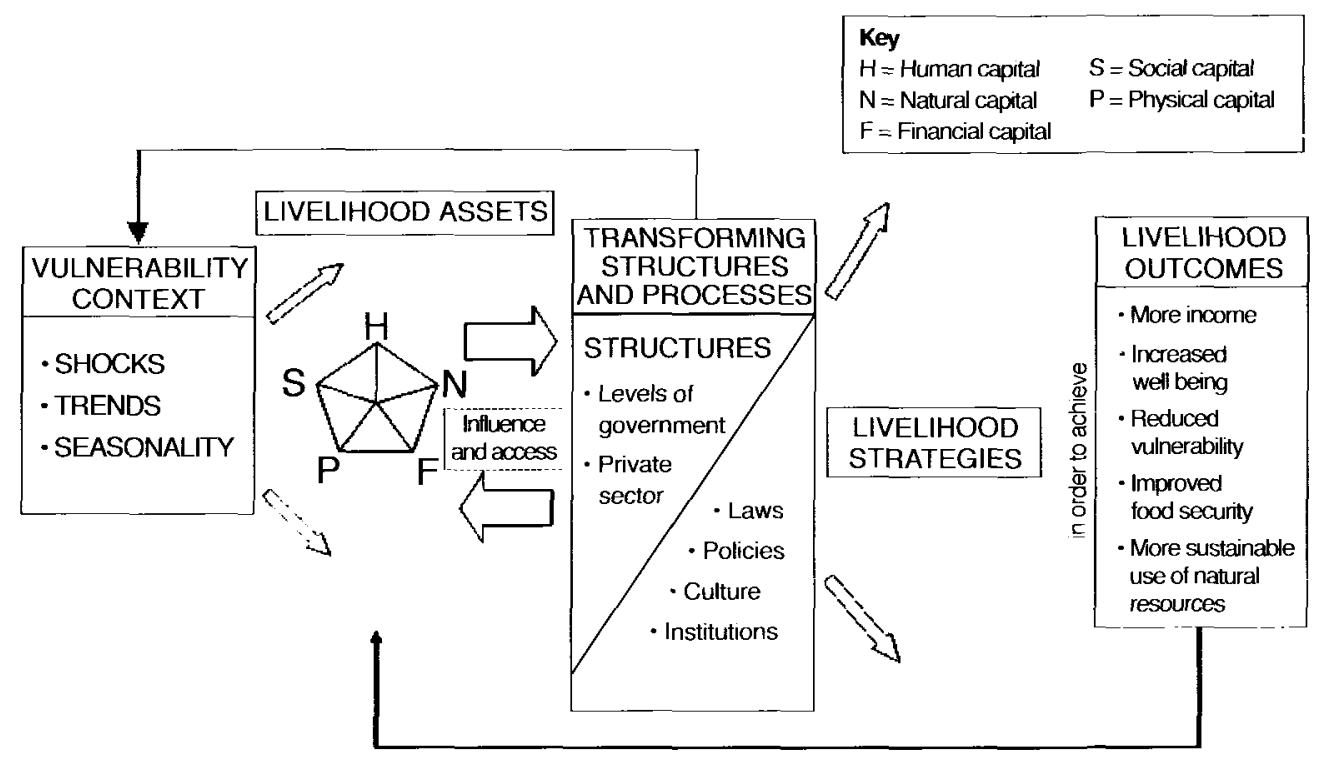

Fig. 1.2. Sustainable Livelihoods Framework (SLF) (from Sustainable Livelihoods Guidance Sheets (DFID), 1999).

Livelihood strategies are conditioned by transforming structures and processes (the institutions, organizations and policies that shape livelihoods by determining access to different types of capital, livelihood strategies and decision-making bodies, and by affecting the terms of exchange for and returns to investment in different types of capital) and affect outcomes for individuals and households (such as changes in income, well-being, vulnerability, food security and natural resource conditions), which feed back to affect their asset endowments over time.

Households (and individuals) may change their livelihood strategies over time as a result of changing opportunities and constraints. Pender (2004) defines a development pathway as a common pattern of change in livelihood strategies, focusing on community-level development pathways. ${ }^{5}$ Examples of common development pathways found in the work of Pender and colleagues in Central America and East Africa include intensification of mixed food grains and livestock production, adoption or expansion of perishable horticultural cash crops, expansion of perennial cash crops and increased off-farm employment or non-farm activity in combination with continued food crop production (Pender, 2004). ${ }^{6}$

As with the SLF, this work emphasizes a complex set of factors influencing livelihood strategies at a given point in time and dynamic processes of change in livelihood strategies, affected by national level driving forces such as: (i) population growth, changes in technologies and market prices; (ii) local conditioning factors such as local population density, market access, agro-ecological conditions, local market 
development and local institutions and organizations; (iii) household level assets; and (iv) government policies, programmes and institutions affecting these (see Fig. 1.3). These factors influence households' choice of income strategy and natural resource management decisions (both part of livelihood strategies) which, in turn, affect outcomes including agricultural production, natural resource conditions and income and welfare, with feedback effects on the causal factors.

Although similar to the SLF, an important difference in this framework of relevance to the study of LFAs is its emphasis on local differences in geographical factors determining comparative advantage, such as agricultural potential and access to markets and infrastructure, in determining livelihood strategies. Based on these considerations, hypotheses can be derived concerning which types of livelihood strategies and development pathways have more potential and are likely to be pursued in different development domains, including LFAs of different types (Pender et al., 2006a).

\section{Key issues}

These concepts and frameworks emphasize the heterogeneity of situations in rural areas of developing countries, including LFAs, and the complex set of factors that may influence livelihood strategies and development pathways and their outcomes. Several key issues arise from

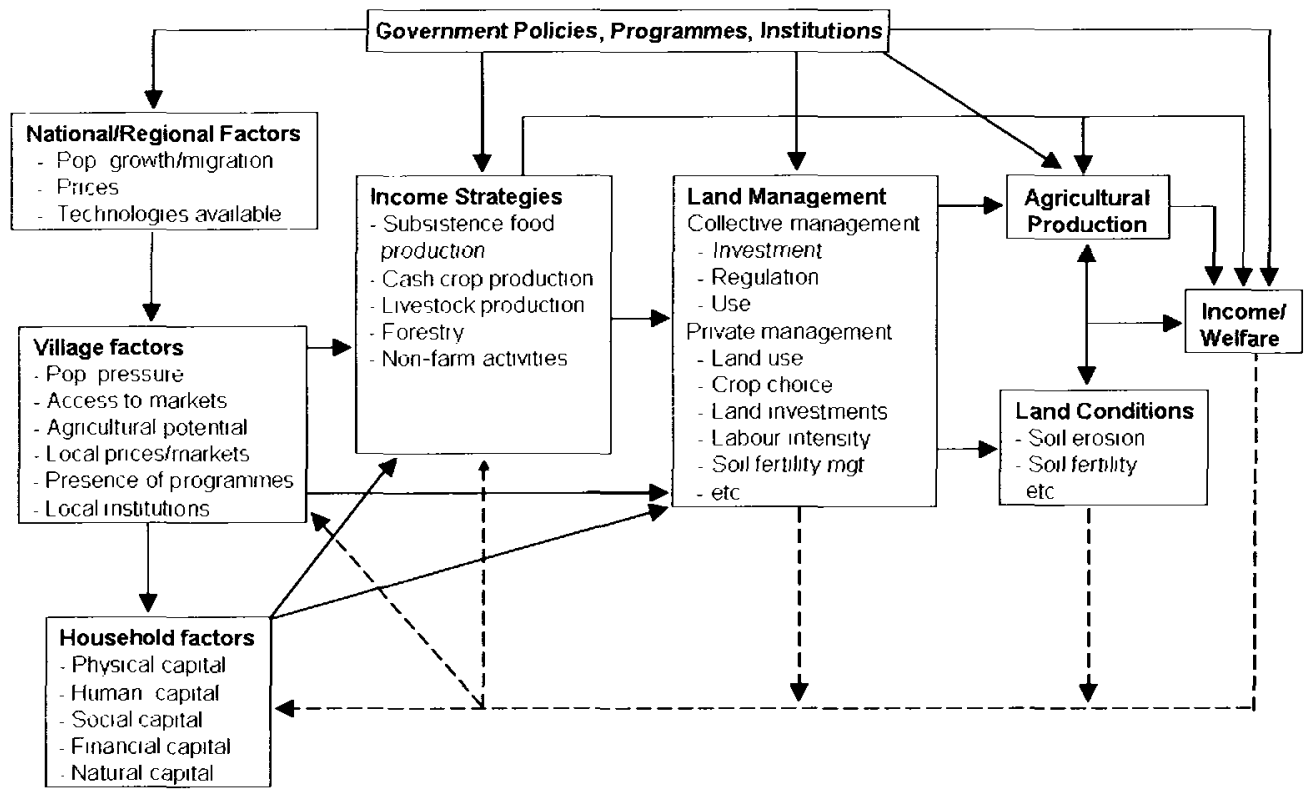

Fig. 1.3. Factors affecting income strategies, land management and their implications (from Nkonya et al., 2004). 
these frameworks as guides for policy-relevant empirical research in LFAs:

1. What livelihood strategies and development pathways are being/have been pursued by individuals, households and communities in L.FAs?

2. What are the impacts of these strategies and pathways on important outcomes such as household income, food security, vulnerability and natural resource degradation?

3. What key factors determine which livelihood strategies and development pathways have been/are being pursued by individuals, households and communities in different contexts of LFAs? What has been the role of policies, institutions, programmes and organizations in promoting or inhibiting development pathways that lead to better outcomes?

4. What opportunities are there to pursue development pathways in the future that will lead to better outcomes? What are the key constraints to realizing these opportunities, and what is the role of policies, institutions, programmes and organizations in facilitating this?

5. What trade-offs or complementarities between different outcomes and across different target groups are likely to result from changes in policies, institutions, programmes and organizations to promote alternative development pathways?

\section{Development pathways for LFAs}

A substantial amount of empirical research has been conducted on many of these issues. We do not attempt a full review of all relevant research to these issues, but will highlight some key findings from recent literature and from some of the studies included in this volume (see Chapters 3, 8, 9 and 10 , this volume).

The empirical literature has shown that a wide variety of livelihood strategies and development pathways are being pursued in LFAs (focusing particularly on income strategies). These usually involve staple food production as a primary or secondary activity, combined with an array of other types of activities, usually including livestock production and often including production of cash crops, off-farm employment and non-farm activities (Ellis, 2000; Nkonya et al., 2004; Pender, 2004; Jansen et al., 2006; Pender and Gebremedhin, 2006; Pender et al., 2006b). Rural non-farm activities and off-farm employment are very important components of household income in many rural areas of developing countries (Reardon, 1997; Ellis, 2000; Barrett et al., 2001; Reardon et al., 2001; Ruben et al., 2001; Stroosnijder and Van Rheenen, 2001; Ellis et al., 2003; Ellis and Bahiigwa, 2003; Ellis and Mdoe, 2003; Nkonya et al., 2004; Jansen et al., 2006; Pender and Gebremedhin, 2006).

However, in many LFAs, such opportunities are limited due to limited access to opportunities in urban areas and limited opportunities 
in local markets resulting from low agricultural incomes (Reardon, 1997; Barrett et al., 2001; Ruben and Pender, 2004). In addition, entry into more highly remunerated segments of the labour market is often hindered by the costs of lumpy investments in training, relocation and/or equipment that are usually required (Ruben and Pender, 2004). Given limited off-farm and non-farm employment opportunities and low agricultural productivity in many LFAs, dependence on food for work (FFW), cash for work (CFW) or other employment-generation or -assistance schemes can be quite high in some LFAs, such as droughtprone areas of Ethiopia (Pender and Gebremedhin, 2006). In such circumstances, income from migration and remittances is often quite important. Other natural resource-based activities, including forestry and fishing, are important in LFAs where such resources are available.

The outcomes of these different livelihood strategies vary across different contexts, although livelihood strategies based primarily on food production generally result in lower incomes and welfare conditions than more diversified livelihoods, especially where there are opportunities for cash crops, higher-value livestock production or nonfarm activities (Ellis, 2000; Holden et al., 2004; Nkonya et al., 2004; Pender, 2004; Jansen et al., 2006; Pender and Gebremedhin, 2006; Place et al., 2006b). Consistent with the prior literature, Roa (Chapter 8, this volume) finds that non-farm income-earning opportunities (through handicrafts production) are critical to the welfare of households in a LFA in the hillsides of the Philippines, and are a key factor differentiating livelihoods and food security in the two communities studied. These findings strengthen the case that expanding the opportunities for nonfarm income are critical for reducing poverty in LFAs.

Available evidence on the impacts of different livelihood strategies on natural resource management and degradation suggests that these impacts are highly context- and resource-specific. Pender et al. $2001 \mathrm{~b}$, d) found that adoption of improved land management practices and improvements in cropland quality and forest availability were greater, but that water availability was also more constrained, in communities where horticultural expansion was occurring than where basic grains production continued to dominate, consistent with the predictions of a bio-economic model developed for a community in central Honduras by Barbier and Bergeron (2001). By contrast, in Uganda, Pender et al. (2004) found little impact of increased horticultural production on most land management practices and indicators of changes in natural resource conditions; while in northern Ethiopia, Pender et al. (2001c) found that horticultural production was associated with improvements in soil fertility in croplands but reduced forest availability.

Production of perennial cash crops such as coffee and bananas is associated with adoption of several improved land management practices (particularly organic practices) in Uganda (Nkonya et al., 2004; Pender et al., 2004), the highlands of Kenya (Place et al., 2006b) and northern Ethiopia (Pender et al., 2001a, c), but with less adoption of 
several land management practices in Honduras (Jansen et al., 2006). Nevertheless, soil fertility depletion is more rapid in perennial production (especially of bananas) in Uganda (Nkonya et al., 2005b).

Off-farm and non-farm activities are associated with greater adoption of purchased inputs such as fertilizer and improved seeds in northern Ethiopia, but with less use of manure and compost, probably due to labour constraints (Pender and Gebremedhin, 2006). Similar results were found in central Honduras, where communities and households pursuing non-farm or off-farm activities were more likely to use agricultural chemicals but less likely to use mulching (Pender et al., 2001b, e).

Access to off-farm employment has theoretically ambiguous impacts on farmers' investments in soil and water conservation (SWC) measures: it can reduce investment by increasing the opportunity cost of labour but can increase it by increasing farmers' ability to finance labour and other costs. The findings of Pender and Kerr (1998) for a village in semi-arid India and of Clay et al. (1998) for Rwanda support the argument that offfarm activities increase SWC investment. Kuiper and Ruben (Chapter 17, this volume) predict that increased access to employment opportunities through migration or CFW programmes will reduce erosion through a different mechanism; i.e. by reducing the intensity of agricultural production.

By contrast, the predictions of a bio-economic model for a community in northern Ethiopia support the expectation that off-farm income reduces investment in SWC and increases erosion (Holden et al., 2004). For Uganda, non-farm activities are associated with increased fallowing and reduced labour use in one recent study (Nkonya et al., 2005b), but have limited impact on land management or labour use in two prior studies (Nkonya et al., 2004; Pender et al., 2004). However, Pender et al. (2004) found that increase in non-farm activities was associated with community perceptions of reduced soil erosion and improved water availability and quality in Uganda, while Nkonya et al. (2004) found that dependence on off-farm income improved soil nutrient balances in eastern Uganda. More evidence is needed on such issues in different contexts to better identify the conditions under which non-farm or offfarm opportunities will reduce or increase land degradation.

As with the outcomes of livelihood strategies, the factors determining livelihood strategies are also context dependent, although some generalizations appear to follow from the available literature. For example, several studies using different methods in different countries find that higher-value cash crop production is more common in areas of higher agricultural potential and better access to markets and infrastructure (Pender et al., 2001c, d, 2004; Nkonya et al., 2004; Jansen et al., 2006; Kruseman et al., 2006; Place et al., 2006a, b). Improved dairy production has also been found to be promoted by favourable agroclimatic conditions and market access in several studies in Kenya (Staal et al., 2002; Place et al., 2006a, b), although results from other East African countries are less clear (Pender et al., 2006b). 
Household-level factors, particularly human capital, also influence livelihood strategies. Education of the household head is particularly important in determining whether more highly remunerated off-farm salary employment or rural non-farm activities can be pursued (Barrett et al., 2001; Reardon et al., 2001; Nkonya et al., 2004). Gender also is a very important determinant of livelihood strategies. In Ethiopia, for example, female-headed households are prevented by a cultural taboo from using oxen, which limits their ability to farm, and often results in such households sharecropping out their land (Benin, 2006; Pender and Gebremedhin, 2006; Tesfaye, Chapter 7, this volume).

In western Kenya, women are often left as land managers, while their husbands migrate for off-farm employment, but lack decision-making authority, which can limit their ability to invest in land improvements or make other agricultural investments (Place et al., 2006b). In Uganda, female-headed households are more likely than male-headed households to use fertilizer, while households with more males use more of some labour-intensive land management practices (Jagger and Pender, 2006). Nevertheless, the difference in crop production between male- and female-headed households is insignificant in Uganda (Nkonya et al., 2004), suggesting that female-headed households are able to overcome labour shortages in agricultural production by using other inputs. Over the longer term, however, women's lack of inheritance rights to land can undermine their ability and incentive to invest in land improvements.

In Honduras, female-headed households are less likely to be involved in off-farm employment and more likely to be focused on basic grain production as their income strategy, increasing the likelihood that such households will remain poor. Consistent with these and many other studies, Ali and Niehof (Chapter 9, this volume) find that gender inequality contributes to lower incomes of female-headed households and poor nutrition of women in Bangladesh, although there has been improvement in women's status as a result of many government and NGO programmes promoting improved female education, alternative livelihoods for women and recovery after a major flood. Although such social changes have not eliminated the gender gap, it appears to be narrowing. These findings suggest that it is possible to address problems caused by gender inequality through targeted programmes for women, although a long-term effort is likely to be needed.

Social capital also has a strong influence on livelihood strategies. In Uganda, differences in ethnicity are a major factor explaining differences in livelihood strategies, and this may be in part due to differences in social capital and experience as well as differences in consumer preferences across ethnic groups (Nkonya et al., 2004). The success of horticultural development for export markets in central Kenya depended to an important extent on the presence of a local merchant class with considerable international trading experience, and upon development of long-term relationships (often personalized) between Kenyan exporters and overseas buyers and distributors (Jaffee, 1995). Dairy production in 
central Kenya depended heavily upon the organization of effective dairy cooperatives, supported by public policies (Staal, 1995). The absence of a vibrant cooperative sector in Ethiopia is one of the important factors explaining the more limited development of the dairy sector around Addis Ababa (Staal, 1995).

Milagrosa and Slangen (Chapter 10, this volume) contribute in an important way to the literature on social capital and its impacts on livelihood strategies by analysing the nature of social capital, its determinants and impacts on vegetable markets in a LFA in the Philippines. They identify several types of social capital in their study area, and find that bonding social capital is more important for vegetable farmers and that bridging social capital is more important for traders. They find several factors that are associated with the development of social capital, including gender, education, religion, age and ethnicity of the farmer, and argue that social capital is essential for the development of vegetable markets. These findings could be helpful in guiding efforts to target promotion of social capital in the Philippines and elsewhere.

Concerning opportunities to promote improved development pathways in LFAs, the means to facilitate this and potential trade-offs or complementarities among outcomes, several studies have addressed these issues in different LFA contexts using bio-economic modelling approaches. Barbier and Bergeron (2001) considered alternative policies and technologies to promote more profitable and sustainable land use in a micro-watershed in central Honduras. They found that infrastructure development (including roads and low-cost irrigation) and dissemination of improved technologies were critical contributors to the development of horticultural production in this community, which was helping to overcome the negative impacts of population growth and declining maize prices.

For a community in northern Ethiopia, Holden et al. (2005) considered alternative policies and programmes to promote sustainable development, and found that the most promising option was to promote tree planting on marginal lands combined with FFW programmes linked to investments in soil and water conservation, which could substantially increase household incomes while contributing to reduced land degradation. Other approaches, such as fertilizer credit and promotion of off-farm employment, had either limited or negative impacts on productivity and were predicted to reduce farmers' investments in SWC and increase erosion, leading to trade-offs between income and sustainability objectives.

Okumu et al. (2002) reached similar conclusions based on their bioeconomic model of a community in central Ethiopia, i.e. that by combining tree planting on marginal lands with technologies to promote more productive crop production, substantial increases in productivity and farm income were possible whilst reducing land degradation. Woelcke et al. (2006) reached less optimistic conclusions using their bioeconomic model of a maize-producing community in eastern Uganda, 
finding that soil nutrient depletion was likely to continue at a rapid pace even with very large subsidies on input or output prices. This is due largely to the low response of maize to various technological options tested in the study villages, leading to low profitability of efforts to promote such options for maize production.

By contrast, Woelcke et al. (2006) found that significant improvements in incomes and nutrient balances are possible by combining improvements in the efficiency of input and output markets with introduction of improved technologies, provision of credit and promotion of labour exchange to relax labour constraints, although nutrient depletion is likely to continue for most households. These findings highlight the importance of providing opportunities for highervalue crops and other livelihood opportunities to increase household welfare, but also demonstrate that such shifts in livelihood strategies may not be sufficient to ensure sustainable use of natural resources. Targeted efforts to address such problems, such as the interlinkage of FFW with conservation objectives, as investigated by Holden et al. (2005), may be necessary.

The findings of Okumu et al. (2002), Holden et al. (2005) and Woelcke et al. (2006) concerning the impacts of multiple interventions suggest (but do not demonstrate) that there may be synergies among different policies if combined. Kuiper and Ruben (Chapter 17, this volume) make an important contribution to the literature on this issue by investigating the impacts of alternative policies or programmes separately and then jointly, and comparing the outcomes. They find that, in most cases studied, there appear to be synergies among policies. For example, combining a cash for work programme with investments in infrastructure to reduce transaction costs leads to a substantially greater reduction in poverty than the sum of the impacts of these individual policies if implemented singly, because the income from the CFW programme helps poorer households to overcome asset limitations that otherwise constrain their ability to take advantage of new market options resulting from reduced transaction costs. This is an important insight, and the method developed to demonstrate such complementarities should be applied in future modelling efforts.

\section{Market Structures and Institutional Development}

Rural households in LFAs are embedded in a socio-economic environment characterized by market imperfections and institutional failure. Analysing the relationship between market access, potential agricultural productivity and development, Dorward (Chapter 19, this volume) envisages three broad pathways for escaping from poor, highrisk and thin markets. First, dramatic investment in market access infrastructure may create pathways through, e.g. extensive (in more remote areas) or intensive (in more accessible areas) livestock systems. 
Such pathways are likely to be least demanding in terms of productivity potential while generating substantial marketable surpluses. A second type of pathway reflects a sudden shift in productivity potential, e.g. through investment in irrigation and/or the adoption of better technologies. To generate a marketable surplus, staple food production may be least demanding of market access (and productivity), but conventional cash crops will certainly be more demanding of both.

The third and probably most common type of pathway is characterized by more incremental technical, institutional and infrastructure investment and is positioned between the two other types. It most likely describes the potential for gradual livelihood improvements in many LFAs without creating major surpluses, but the development of horticultural crops for local and international markets is likely to fit this pathway as well, although conditional on substantial market access and marketing effort. In general, intensification of farming activities, diversification into higher-value crops and farm size (and structure) improvement need to be matched by improved access to markets in order to absorb surplus produce.

Similar arguments for market access apply for the diversification out of agriculture as part of a household's livelihood strategy (see also Niehof, 2004; Brons et al., Chapter 3, this volume). These strategies or pathways can take two forms: (i) local reliance on non-agricultural activities, initially through labour diversification, but in case of selfemployment requiring a certain amount of start-up capital; and (ii) migration to other areas to find employment in urban areas or more productive agricultural activities elsewhere. The migration strategy usually assumes relatively high capital endowments to finance new activities elsewhere (in addition to some education, communication and information networks). Sources of capital can be accumulated from past remittances, savings from agricultural surpluses or other sources of local wealth. In both strategies, overall labour mobility is likely to be constrained by initial inequalities in wealth and human capital coupled with an imperfect capital market.

Interestingly, all pathways for LFA development imply improved access to, or functioning of, product and factor markets, as documented in a number of case studies in this volume (see Chapters 12-15). Although the case studies usually focus on particular elements of a livelihood strategy, in reality a multitude of pathways or strategies can be observed in most regions, reflecting unique local comparative advantages (Pender, 2004). This phenomenon strengthens the argument for market development as a prerequisite that is largely independent of the particular pathway chosen.

The general need for market development also reduces somewhat the importance attached by different authors to appropriate strategies for LFAs. Thus, FAO/World Bank (2001) emphasizes exil from agriculture (migration), off-farm activities and on-farm diversification (in that order) as strategies for low-potential areas (defined as mainly rain-fed highlands and 
drylands). Dorward, Chapter 19, this volume, argues that (sustainable) intensification ('stepping up') migration and non-agricultural activities ('stepping out') are promising strategies. Whatever combination of strategies is adopted, the realization of an improvement of livelihoods in LFAs crucially depends on a better functioning product and factor markets.

\section{Market imperfections}

Markets are one particular form of exchange mechanisms, and the extent to which they tend to function better than other ways of coordination or exchange (formal and informal contracts, vertical integration, social networks) depends on a variety of factors. Ahmed and Peerlings, Chapter 16. this volume, mention transaction cost, information, uncertainty, specificity of transaction investment, frequency of exchange, number of actors, entry and exit cost, product heterogeneity and (natural resource) externalities as factors explaining market imperfections. With high transaction cost and limited information, product as well as factor markets may be thin or even missing. Poor infrastructure may cause shallow markets that are regionally dispersed and show high price fluctuations. Absence of credit facilities, e.g. because land markets are missing so that land has no collateral function, can lead to interlinked markets for, e.g. input supply, output and credit. Asymmetric information on the side of buyers (traders) notoriously results in imperfect competition favouring traders. Government interventions can seriously distort markets (and create opportunities for rent seeking).

As many of the case studies show, such market imperfections tend to be more frequent in and/or harmful for LFAs. As a consequence, LFAs suffer substantial efficiency losses compared with other regions, where a more favourable resource position has often enabled earlier market development. Studies by Fan and Chan-Kang (2004) show how investment in rural infrastructure can redress such inefficiencies by reducing transaction cost and capturing externalities. Their work points to high returns on investment and large contributions to poverty alleviation, relative to better situated areas, of roads and public utilities, education, research and development and, to a lesser extent, irrigation.

\section{Product markets}

Most of the cases focus mainly on product markets: (i) food staples (rice in China, Chen Le and Peerlings, Chapter 15, this volume); (ii) vegetables in the Philippines (Milagrosa and Slangen, Chapter 10, this volume); (iii) food and cash crops in Ethiopia (Jaleta and Gardebroek, Chapter 14, this volume); and (iv) apparel exports from Bangladesh (Ahmed and Peerlings, Chapter 16, this volume). 
The transition in rice marketing from formerly state-owned trading companies towards a system with private traders in three villages in Jiangxi Province, south-east China, illustrates a variety of market imperfections due to unfavourable natural conditions and high transportation costs. After the reforms, markets remain thin, distorted and oligopsonistic, with traders suffering from a missing credit market. Moreover, local farmers are isolated from changes in the main consumption centres so that price transmission is incomplete. Trust and informal relationships (networks) therefore continue to play an important role in exchange between farmers and traders. However, communication by cell phones has reduced search cost and strengthened the position of surplus farmers. Overall, and depending on the nature of the initial market imperfections, those farmers situated closest to consumption centres who are able to offer larger surpluses and have good market access are expected to gain most from further liberalization and deregulation.

Vegetable farming (carrots, potatoes and cabbage) in the province of Benguet in the northern Philippines, an important production area, is characterized by poor market access due to low-quality roads and risk of landslides, and by limited agricultural potential as a result of soil depletion and lack of irrigation facilities. The area provides the bulk of vegetables for the national market, but local trading posts are incapable of handling harvest overflows (shallow markets), postharvest losses are high and physical market infrastructure for cold storage, handling and communication is insufficient. Despite strong interpersonal networks, trust within the farming community is low, and farmers are suspicious of traders in matters of weight, grade and price of vegetables, resulting in high transaction cost. The latter is related to asymmetric information, giving traders power over an individual farmer. Produce is normally sold using spot markets, but farmers prefer to deal with well-known traders with whom they are acquainted. These traders also supply them with inputs, cash advances and gifts, thereby creating interlinked transactions.

The Ethiopian study focuses on farm household land and labour decision making under imperfect factor and product markets in central and eastern Ethiopia. High transaction cost to enter factor or products markets causes the production and consumption decisions in a farm household to become non-separable. Households satisfy their own consumption needs first before considering allocating resources to highvalue cash crops, the price of which can bear high transaction cost. Risk in those circumstances may further aggravate the wedge between buying and selling prices, making households in these areas almost autarkic.

The empirical results show that, in this environment of risk and high transaction cost, it is only those households who have access to their own farm capilal (in this case a motor pump for irrigation) and nonfarm income sources, that can afford to diversify into high-value crops. The resulting higher land and labour productivity encourages them 
subsequently to rent more land and employ more labour. The shift towards labour-intensive vegetables, in turn, contributes to higher incomes for landless workers.

The rapid increase of apparel exports by Bangladesh under the former (and discriminatory) Multi-Fibre Arrangement (MFA) illustrates the major advantages enjoyed by an exit-out-of-agriculture strategy for LFAs. Under the MFA, import quotas for apparel in the markets of Europe and North America were less restrictive for Bangladesh than for its competitors. As a result, Bangladesh enjoyed import tariff and import quota preferences that gave the country an (artificial) competitive edge over potentially stronger producers like India and China, as a result of an (intended) market distortion.

Simulations using a GTAP general equilibrium approach of different liberalization scenarios confirm the substantial welfare gains Bangladesh enjoyed under the MFA regime. Almost 2 million workers, more than $90 \%$ female, are currently employed by the export industry, of whom threequarters are migrants from poor rural areas that are able to send substantial remittances back home. Better infrastructure and communications, as well as product diversification, are needed to improve the competitiveness of the sector and retain the past achievements under less-distorted market conditions.

\section{Interlinked factor and product markets}

Market configurations in many LFAs are characterized by strong imperfections at major factor markets, as well as interlinkages between factor and product markets, both for reducing transaction costs and for managing risk. The Ethiopia study (Jaleta and Gardebroek, Chapter 14, this volume) on decision making regarding food and cash crops shows how imperfections in the product market affect land and labour allocation within the household, driving a wedge between the factor's (lower) internal marginal value product and the possible remuneration elsewhere. Farmers are aware of this discrepancy, but high transaction costs in the product market justify the fulfilment of consumption needs from own resources, even if this means forgoing higher returns outside the household. Such interlinkages between different markets are typical of many LFAs, and have been illustrated in two more cases: (i) cooking banana, a staple and cash crop in Uganda (Bagamba et al., Chapter 12, this volume); and (ii) participation in factor markets in the previously mentioned rice production area in Jangxi Province, China (Feng et al., Chapter 13, this volume).

Cooking banana is a key staple food in Uganda and is produced mainly for own consumption in low-elevation areas and for both consumption and sale at higher levels of elevation. It has one of the best functioning commodity markets in the country. In response to poorly functioning financial and insurance markets, farmers react by diversifying 
their crops at the expense of banana, giving preference to subsistence crops, engaging in off-farm employment and limiting the extent to which they can grow labour-intensive (cash) crops. It is this behaviour that explains why, in areas suitable for banana production, farmers allocate more labour and land to sweet potato and cassava than to banana.

For the same reason, remote households allocate more resources to the production of coffee (to obtain cash) and maize (for home consumption), despite their low-value marginal products. As a result, farmers close to consumption centres and in competition with off-farm activities devote more of their household labour to low-value subsistence crops rather than to higher-value bananas for sale. In more remote areas, with limited off-farm opportunities, considerably more labour is used for banana production. It is therefore the functioning of other markets that enters into the explanation of factor allocation in banana production in different regions.

In a sequel to the earlier Chinese study, an analysis was made of village household participation in the land and labour market, showing that these decisions are taken simultaneously, thereby linking the two markets. To explain this phenomenon, the size of a farmer's land holding plays an important role. Households with small land endowments may not be wealthy enough to utilize off-farm employment, whereas those with larger land holdings are likely to have difficulties renting out their land and will prefer to work on-farm instead.

In general, the likelihood of being involved in migration shows an inverted U-shaped relationship with the average age of adults in the household. The turning point comes earliest for those that rent in land (and need labour), and comes latest for households renting out. The larger the household size and the fewer the number of dependents the more likely is migration, but not local, off-farm employment (probably because food requirements remain the same for local employment while having less labour on the farm). Durable household assets, possession of a land contract and access to a migration network all favour outmigration. As such, this case emphasizes the important role of a (temporary) 'stepping out' strategy to improve the livelihood of LFA households.

\section{Other options: looking beyond agriculture}

To improve living conditions in LFAs many development pathways are conceivable, as shown in this volume. The gradual conversion of lowproductivity systems through suitable technologies, economic incentives (largely through well-functioning markets) and support services and institutional innovation, emphasizes the important role external factors can play. In general, what happens outside agriculture can be an important force for LFA development, as Lipper et al. (Chapter 18, this volume) argue. Using an induced innovation-type framework, they show 
for different categories of dry-land farming how economic development and trade outside an LFA, coupled with local investment in irrigation and a good market infrastructure, have transformed these farming systems into highly developed and competitive systems in many parts of the world.

Such transformations can currently be observed in some LFAs (and other rural areas for that matter) where the rapid development of the non-farm rural economy, with newly emerging markets and support services, pulls primary agriculture out of a state of low productivity (Hazell et al., 2006). The rapid rise of supermarkets, changes in consumer preferences away from 'bulk' quality and the concurrent changes in food chain management and (international) outsourcing, have created new opportunities for those agricultural suppliers able to meet the technical, sanitary and phytosanitary standards of processing firms and exporters.

New challenges for LFA producers are emerging here, as the exchange mechanisms they face can be either contract farming or spot markets and are characterized by considerable product differentiation. Both institutional and market support have proved indispensable to farmers in order to satisfy successfully the requirements posed by modern food chains (Ruben et al., 2006).

Another relatively new opportunity for LFA development is the provision of ecosystem services, as put forward in Lipper et al. (Chapter 18, this volume). To make a lasting contribution to the livelihoods of poor households, the provision of such environmental services needs to be integrated in the development pathways for specific LFAs, and funding based on willingness to pay needs to be mobilized to actually pay for these services as an additional source of income. In principle, such schemes internalize positive externalities thus far provided for free (and usually known to both private actors and local authorities). To the extent that property rights to land and water can be recognized and assigned to households, a market for these services can be created where previously none existed.

Public international demand for ecoservices like climate change mitigation, biodiversity conservation and the management of water resources is emerging (for instance, through the Global Environmental Fund) and, in some countries, national public demand is institutionalized (China's programme to reduce soil erosion and water pollution; Brazil's biodiversity conservation programme). Private sector purchase of ecoservices is developing as well, as are market-based implementation systems. What is currently lacking is knowledge about the type of institutions that can facilitate the exchange of environmental services for payments at low transaction cost and certified product quality. Certain NGOs provide these mechanisms, but the Iransaction cost remains prohibitively high for successful upscaling. 


\section{Implications for Policy and Research}

Based on our review of the options for farming systems intensification and sustainable livelihoods that are available for rural households in LFAs, we can discuss the effectiveness of policy instruments that may support the resilience of LFA farming systems and their contributions for escaping spatial poverty traps in LFAs. Targeting of incentives towards resource-poor households and remote regions will be required to guarantee simultaneous increase in the returns to land and labour. Otherwise, institutional strategies for enhancing collective action and reducing transaction costs tend to be critically important for enhancing farmers' investments and enabling them to exploit their comparative advantage.

\section{Policy incentives}

Public investments in LFAs have the potential to generate competitive, if not greater, agricultural growth on the margin than comparable investments in many high-potential areas, with a greater impact on the poverty and environmental problems. Recent studies on India (Fan et al., 2000), China (Fan and Hazell, 2001) and Uganda (Fan and Chan-Kang, 2004) have shown that many investments in LFAs now give comparable or higher returns than investments in irrigated and high-potential rainfed areas, having a greater impact on poverty as well. Targeting investments in roads, agricultural research and education in LFAs seems to offer good prospects for increasing productivity and contributes most to poverty reduction.

In Uganda, sizeable differences are also observed among investments across regions. Agricultural R\&D and feeder roads appeared to be the most profitable investments. In terms of poverty reduction, all types of investments apart from health care generated the highest returns in the northern region, where most of the poor in Uganda live, whereas relatively small poverty impacts occurred in the most developed central region. In all regions, agricultural $R \& D$ was the most effective investment for cutting poverty. Feeder roads proved the second most effective investment whereas health had, overall, a small impact on poverty reduction.

On the whole, returns - in terms of agricultural productivity and poverty - are still quite sizeable in Uganda's most developed regions. This suggests that, in eastern Africa in some of the high-potential areas, returns to public investment are still high. These results contrast markedly with those for Asian countries, where for most investments the estimated returns in the less-developed areas are substantially higher than those in the high-potential areas.

The transformation of production systems and livelihood strategies in LFAs also requires a set of local incentives to enhance the responsive 
capacity of communities and households (Vitale and Sanders, 2002). Input support is frequently mentioned as an incentive for enhancing soil and water conservation investment and crop diversification in mixed cropping systems, and for pasture and tree crop improvement.

Results of input support measures are, however, rather mixed, especially when implicit subsidies are involved. Even while farmers have clear perceptions of the causes and effects of soil degradation, general adoption of land conservation measures rarely takes place. Effective incentive regimes for sustainable land management and smallscale irrigation programmes offer support for covering sunk costs and, furthermore, focus on reinforcing the marketing structure (higher-value crops, crop diversification) as a device for enabling farmers to make the required investments. Furthermore, soil conservation and fertility strategies that effectively combine short- and long-term interests of farmers are likely to be better accepted by farmers (Erenstein, 1999).

Rural financial institutions, traditional rotating savings and credit schemes (ROSCAs) have proved successful in providing access to resources for agricultural intensification and income diversification. Local grouplending schemes can offer a cost-efficient system of insurance against risk, but tend to be biased in favour of wealthier farmers (Udry, 1990; Dercon, 1998). Institutional alternatives of area-based insurance that offer poor rural households a suitable risk management option have now been developed (Skees et al., 1999). ${ }^{8}$

Animal systems usually require credit services with a long grace period. Drought assistance schemes are used to support down-stocking of animals in order to reduce stocking rates and to maintain cattle prices during periods of high market supply. ${ }^{9}$ In Indonesia, livestock acquisition for landless farmers is promoted through in-kind credit facilities. Smallholder dairy credit in Kenya and Bangladesh provided through local NGOs was successful in increasing productivity and income, focusing on simultaneous improvements in genetics, milking equipment, feed supplements, traction implements, marketing and processing (De Haan et al., 2001).

Water charges can be introduced as a step towards efficient water distribution according to the real opportunity costs. In perspective, tradeable water rights are considered an effective mechanism for optimizing water allocation, although measurement problems still inhibit a more general application (Pingali and Rosegrant, 2001). Watershed protection programmes that focus attention on hillside and upland conservation and sediment control may offer the additional benefits of hydro-energy production and wildlife and biodiversity conservation.

Food-for-work activities are frequently used for rural infrastructure construction and the creation of soil and water conservation structures. Drought-relief interventions that rely on food-for-work programmes can be helpful in relieving the pressure on natural resources. The total costs of food-for-work programmes are, however, extremely high (transport 
costs commonly take half of the resources) and participants typically accept a lower cash wage to do the same work (Barrett and Maxwell, 2005).

Perennial tree crop and agro-pastoral systems can be stimulated through sales of environmental services. Agroforestry and improved pastures reduce the build-up of carbon dioxide and other greenhouse gases (Dixon, 1995). Widespread adoption of agroforestry and other methods of improved soil management in the tropics could lead to a relative increase in soil carbon storage of about $1 \%$. Indirect effects can be much greater, reducing carbon dioxide emissions caused by forest clearance. In a similar vein, mixed cropping systems in highland and rainfed areas could generate local markets for environmental services for their contributions to water management at watershed level.

Promotion of integrated pest (IPM) and nutrient management (INM) practices in mixed highland and rainfed systems requires a thorough training and participatory involvement of farmers to create sufficient knowledge about biological and agronomic control practices. Farmers field schools (FFS) that have offered such training in various Asian countries provided a useful framework for experimental learning based on field trials with different management practices, followed by joint damage or impact assessment. Recent evidence indicates, however, that poor upscaling has seriously reduced the impact of the FFS programme in Indonesia.

Market development based on the domestication of trees in agroforestry systems offers some prospects for non-timber forest products, like fruit, flesh, kernels and seedoils. ICRAF identified promising perspectives for particular products in the humid and semi-arid lowlands of West Africa, the southern African plateau and in the Amazon region (ICRAF, 1999). Success depends on further improvement of plant traits (clonal forestry), increasing the length of the productive season, reducing tree height and improving yield and product quality. More importantly, access to export markets requires close collaboration with the food industry engaged in the development of novel foods (e.g. antimicrobial properties of some kernels for dental toothpaste, fruit pulp applications in processed foods, etc.).

Finally, improved chain integration can be helpful in creating prospects for sustainable resource management for tropical fruit, fish and vegetables based on stable access to markets and information that enables additional investment in quality management for increasing value added (Kuyvenhoven and Bigman, 2002). While public market information systems formerly received much attention, reliable private marketing arrangements are now considered more important for enhancing stable market access. Local processing also creates major rural, non-farm employment opportunities. New procedures and practices for organizing food supply networks - with direct contractual ties between primary producers, processors and retailers - have emerged to cope with food quality, safety and health demands (Glover, 1990; Key and Runsten. 
1999). These practices require the development of grades and standards, together with agreements on best practices.

\section{Properly rights and community organization}

Supporting the process of sustainable rural development and agricultural intensification in highland and dryland areas requires institutional structures that guarantee local stakeholders equitable access and legally secure entitlements to assets, knowledge and information (Knox et al., 2002). This would create the necessary conditions for demand-driven and participatory processes of local technology development that are responsive to the needs of poor people. Community social capital is of primary importance for gaining access to markets and exchange networks. Land use intensification in LFAs will become more market oriented when local farmers' groups are able to achieve better market integration for finding stable and rewarding outlets.

When the property rights of the rural poor to critical assets like land, water, trees and pastures are sufficiently ensured and local communities are able to exercise control over their resources, economic incentives for initiating an endogenous process of technological innovations can be set in motion. Improved resource management strategies for LFAs require effective enforcement of property rights and a high degree of collective action. Agroforestry and perennial tree crops are long-term investments, and individual farmers will only plant trees if they have secure (land or tree) property rights or leasehold arrangements enabling them capture the future returns from their investment.

Improving shifting cultivation in highland areas relies on improved fallow, with investments in contour ridges, formation terraces and fastgrowing, multi-purpose tree species that provide early returns. Control of traditional slash-and-burn agriculture within community-based watershed development and integrated nutrient and pest management programmes puts a high demand on collective action. Migratory herding and transhumant pastoralism in densely populated semi-arid areas increasingly face land conflicts with rural communities regarding grazing and water rights, and grazing codes are put forward for conflict resolution. Agro-pastoral systems that use simple erosion control measures, water-harvesting technologies and drought-resistant varieties can be adopted by individual farmers as long as stable use rights are in place. Mixed rainfed cropping in (semi-)arid areas relying on soil and water conservation structures and weed control measures requires the consolidation of fragmented holdings and regulatory measures regarding access to land and water at community level.

In highland LFAs, property rights and tenure security strongly influence prospects for agroforestry development. However, customary land tenure systems in East Africa and Asia need not to be an impediment for agroforestry investment (Bruce and Migot-Adholla, 
1993). In practice, land rights have become more individualized after investments in tree planting took place. Community forestry systems are gradually evolving towards individual tenure regimes (Otsuka and Place, 2001). Migrant herders rely on mobility of cattle over long distances as a strategy to take advantage of spatial ecosystem variability. Recognition of customary rights (pastoral codes) can be an effective way of reducing overgrazing, but fiscal and price instruments (pasture fees) are less effective in controlling stocking rates. In Mongolia, the legal recognition of customary forms of pasture tenure provides better security to nomads. Similarly, artisanal fisheries communities define territorial use rights for matching catching capacity with resource productivity, guaranteeing community members sequential access to different fisheries areas (Allison and Ellis, 2001).

Pastoral organizations have also been successful in mobilizing producers around input provision, but proved less effective in establishing rangeland management procedures; customary institutions show considerably better performance in this respect. Grazing and water fees have been faced with implementation difficulties, and long-term leasehold contracts proved to be a more effective means for controlling pasture degradation. Upgrading of feed and water resources is most successful in livestock programmes that focus on marketing and processing in areas with increasing land scarcity. Forward market linkages thus seem to be an important driver for technology adoption.

The reversal of rangeland degradation with agro-pastoral practices requires clear regimes of property or grazing rights. Common property of arid rangelands with well-identified membership, entry boundaries and management rules and regulations can be an effective vehicle for establishing coordination between independent livestock owners (McCarthy et al., 1999). In addition, insurance systems that are able to reduce risk support the adjustment of stocking levels and the intensification of pasture management, although at the cost of greater heterogeneity amongst herders and possibly reduced willingness for cooperation (Hazell, 1999).

Secure tenure arrangements are especially important in encouraging farmers to make major investments in soil fertility management and watershed conservation. Well-defined (individual or community) property rights provide incentives to farmers to control land degradation and to enhance their efforts in appropriate soil and water conservation measures. In Niger and Burkina Faso, secure family fields receive twice as much manure and fertilizers as village fields (Stroosnijder and Van Rheenen, 2001). In South-east Asia, short-term sharecropping arrangements may hinder investments in soil and water conservation, but long-term leasehold contracts provide substantial positive incentives for improved soil fertility management (Hayami and Otsuka, 1993).

Local organizations have been particularly successful in empowering communities in overcoming social and institutional constraints. Improving resource management in LFAs using participatory research methods can 
build on farmers' own knowledge and experiences (Goma et al., 2001; Zurayek et al., 2001). Watershed protection programmes that focus attention on hillside and upland conservation and sediment control ask for a participatory approach involving a broad coalition of all stakeholders, as well as a clear recognition of the 'public goods' character of watershed services (De Graaff, 1996; McNeely, 2001). Decentralization of management and community participation contributed to the success of watershed programmes in India (Kerr et al., 2001). Additional financial resources could be mobilized through the generation of hydro-energy, tourism and the sale of environmental services like wildlife, biodiversity conservation and carbon fixation.

Successful implementation of water management programmes that benefit poor households is highly dependent on the regulation of water rights and the procedures for water distribution. The social capital of village institutions in Asia provides a wide basis for putting user organizations in charge of water management and distribution (MeinzenDick, 1997). Clear rules and regulations, as well as proper implementation and enforcement strategies, are needed to guarantee user participation. In a similar vein, control of soil erosion requires an institutional framework for nutrient management at regional level in order to control off-site effects. Strong community organization amongst farmers is also required for controlling plant diseases that are easily spread, and therefore require collective action. Early detection and understanding of the field ecology enables farmers to determine critical levels of infestation and the appropriate moment when interventions are required.

Institutional development of service provision, extension and training are essential components for sustainable intensification. Decentralization of authority and empowerment of local communities are of key importance in overcoming resource constraints and contributing to capacity building. Private delivery of inputs and services can be effective for reaching poor households, although sanitary services related to disease surveillance and food safety surveillance maintain a public goods character (Umali et al., 1992). Community social capital is often of primary importance in gaining access to markets and exchange networks. Farming systems intensification in LFAs can become more market driven when local farmers groups are able to establish stable and rewarding outlets. However, for those services where missing markets persist (e.g. for carbon fixation, food safety surveillance and insurance), collective action, e.g. through state intervention, is still required.

\section{Policy targeting}

The identification of particular geographical areas for targeting LFA development efforts is based on the assumption that location is a prime determinant for poverty. ${ }^{10}$ Whereas large inequalities in living standards and poverty incidence are registered between different geographical 
settings, focusing attention on such 'backward areas' can substantially improve targeting efficiency (Bigman and Fofack, 2000).

Empirical evidence derived from several studies on geographical poverty traps indicates that geographic factors (residence) have a strong and significant effect on household wealth and consumption (Ravallion and Jalan, 1996; Minot, 2000). Initial conditions consistently reduce returns to private investment, and the stock of community capital has a strong negative effect on the productivity of private investment. In addition, health status is usually lower and educational levels are limited, thus further reducing the returns to labour. This suggests that households living in LFAs face critical geographical constraints and meet consumption levels that are substantially lower than those of otherwise identical households in better areas.

Whereas broad spatial targeting based on access and distance (road density) criteria can be effective for reducing poverty due to adverse (man-made and natural) geographic variables, differences in the distribution of private assets may negatively influence income distribution (Escobal, 2005). Therefore, complementarities between social and physical infrastructure and the role of local institutions need to be seriously considered. Other studies suggest that substantial disaggregation is required and that attention should be focused on relatively small administrative units (districts, villages), since a large part of the variation in household income can be attributed to within-village differences in resource endowments (Baker and Grosh, 1994; Jayne et al., 2003; Elbers et al., 2004).

Within the framework of livelihood studies, far more attention is given to social heterogeneity and the identification of 'people at risk'. Vulnerable population groups are identified according to criteria of gender, age, ethnicity, household size and education. It is noted, however, that some of these individual characteristics tend to be geographically correlated, since disadvantaged groups are likely to be concentrated in remote and less productive areas (Van der Walle and Gunewardena, 2001). Given equal endowments and location, disadvantaged and minority groups still receive lower returns to given individual and household characteristics. Lower returns may, however, be contested by behavioural responses that partly compensate for geographical disadvantages. Even while the absolute advantage of poor areas is limited, a wide diversity of development pathways can be identified based on specific local, and individual relative, advantage (Pender, 2004).

\section{Frontiers for future research ${ }^{11}$}

Many of the studies demonstrate the primary importance of identifying profitable options for farmers in LFAs, if poverty is to be reduced. Despite the importance of profitability of livelihood options, there is still 
a dearth of information about this. Recent literature has shed light upon the profitability of some options in particular circumstances, but much more needs to be known in order to develop effective targeted interventions. There is still limited systematic and reliable information collected on a regular basis about the profitability of different crop, livestock or forestry combinations in different types of LFAs, or the profitability of land management practices linked to these different livelihood activities. Beyond estimating private profitability, information on the social profitability of alternative activities in different domains is also needed, taking into account externalities, market price distortions and non-marketed inputs and outputs.

In addition, the social profitability of alternative public programmes and investments also needs to be better understood, to help guide development investors and governments as to where the highest returns can be expected. The returns, costs, risks and social and environmental impacts of other public investments - such as investments in infrastructure, education, agricultural research and extension, and others - are also not well quantified. More research is needed to estimate the costs, risks and social and environmental impacts of alternative investments.

To better assess such impacts, more long-term research with panel data sets and dynamic models is needed to better understand the dynamic relationships between: (i) policy and programme interventions; (ii) local institutions and endowments of physical, human, natural, financial and social capital; (iii) community and household responses in terms of collective action, livelihood strategies and land management practices; (iv) changes in production, income, land degradation and other outcomes; and ( $v$ ) the feedback effects of these responses and outcomes on interventions, local institutions and endowments, and future responses. It is difficult to know the extent to which communities and households are trapped in a downward spiral or poverty trap, stagnation, a virtuous upward spiral or other kind of dynamic development path, or what the most effective interventions will be to promote sustainable development, without better diagnosis of the problems and the key causal factors and feedback relationships that are driving them.

For example, some communities may be falling deeper into poverty and depleting all of their endowments as a result of a lack of sufficiently profitable investment opportunities for any type of capital. Unless profitable investments of some kind can be identified, a sustainable development solution may not be possible without promoting large-scale emigration out of such areas. In other cases, communities and households may be depleting their natural capital but investing in other forms of capital that are yielding higher returns (Pender, 1998). Such a development path may be sustainable as long as households are aware of the depletion of natural capital, and will eventually address it adequately as the returns from investing in natural capital increase 
relative to the returns from investing in other types of capital (Pender, 1998). Alternatively, they may not be sufficiently aware of the depletion, may not have adequate incentive or ability to address it because of externalities or other market failures, or may be crossing a threshold into a poverty-degradation trap in which the costs are too high or the marginal returns too low to maintain or restore the natural capital stock (Pender, 1998; Barrett et al., 2002).

In order to prescribe effective actions, it is essential to diagnose the problem correctly. If there is sufficient awareness and no major market failure, the problem is likely to take care of itself as the relative returns to investment in different types of capital adjust (Pender, 1998). If there is insufficient awareness of the degradation problem, educational and technical assistance approaches may be sufficient to solve it. If the problem is due to market failures or a degradation trap, more intervention will be necessary to address these causes. Without more information to diagnose what kind of dynamic situations that communities and households are facing, it will be difficult to prescribe effective remedies.

Even without dynamic information, however, it would be very useful to identify areas and household types for which profitable livelihoods and land management practices are feasible, but are not being pursued. Where such untapped potentials exist, it is useful to investigate the reasons why, and identify the extent to which policies, public investments and programmes could facilitate fulfilment of these potentials.

Investigation of synergies among different policies using a modelling approach, as demonstrated by Kuiper and Ruben (Chapter 17, this volume), can be very useful for this. Past research and the research in this book has identified some examples of such potentials, such as production of high-value commodities in areas of high potential close to urban markets and tree-planting activities in many other areas, and has also provided some insights into the reasons why such potentials are not being more widely exploited. Further case study research into these and other promising livelihood options could yield valuable insights.

More historical case study research investigating the dynamics of changes in income strategies, land use, land management, land degradation, productivity and welfare outcomes - such as the influential case study of Machakos by Tiffen et al. (1994) - would also be valuable. Such long-term historical studies can yield a wealth of insights into the processes of land degradation or improvement, and also into key driving forces and responses that are not achievable using only cross-sectional surveys of the type emphasized by many of the studies in this book. However, the conclusions of such a focused case study can easily be over-generalized.

Similar studies are needed in different development domains and different historical, political and social contexts to draw more robust and generalizable conclusions about the dynamics of livelihoods and resource degradation, causes and responses in different LFAs. A 
combination of quantitative survey and qualitative case study research methods, building on the strengths and addressing the weaknesses of each approach, is more likely to produce clear and robust conclusions than reliance on any single approach.

Finally, the scale of interventions and their impacts also need to be better understood, and have been addressed in several studies (see Lopez Ridaura et al., Chapter 2, and Dorward, Chapter 19, this volume). Interventions that are able to increase production and household income when pursued on a small scale may lead to quite different impacts when implemented on a large scale. ${ }^{12}$

Research tracing impacts across scales is needed, from the assessment of impacts of policy and programme interventions on adoption decisions at the plot - and household scale and their implications for local natural resource conditions - to the impacts on prices and other outcomes at the community, national and regional scales. The feedback effects occurring between these scales must be better understood and accounted for in planning interventions, if the benefits of such interventions are to be maximized and unintended negative impacts are to be minimized. The use of integrated bioeconomic models at farm-household, community and higher scales (as illustrated by Jansen et al., Chapter 6 and Kuiper and Ruben, Chapter 17, this volume) is likely to be essential for a better understanding of these impacts.

\section{Endnotes}

1 LFAs also carry a disproportionate burden with vector-borne diseases (e.g. malaria, plague) hecause of lack of preventive and curative care, and are affected by the threats of HIV/AIDS, in part because return migrants bring the disease back home. The associated decline in the available labour force of prime working age is leading to rising dependency ratios, and available labour for maintaining and improving natural resources becomes strongly reduced (Niehof, 2004). Income shortfalls affect food consumption, while seasonal labour shortages lead to the removal of children from school and the decline of gross primary enrolment rates. Rising health expenditures for medical treatment force households to deplete their savings and eventually sell assets. In addition, agricultural knowledge and farm management skills get lost and traditional social security systems may become disrupted.

2 Walker of al. (2000) assert that this is not the case in the northern Andes region, where agro-ecological and market conditions are more favourable in the Andes mountains.

3 The UNCCD defines drylands as arid (with average length of growing period (LGP) < 60 days), semi-arid (LGP 60-119 days) or dry sub-humid (LGP 120-179 days) areas.

4 The figures for shares of land seriously degraded are from Scherr (1999), who combined the GLASOD categories of 'moderately degraded', 'strongly degraded' and 'extremely degraded' into the class of 'seriously degraded'. Oldeman et al. (1991) defined moderately degraded soils as having suffered greatly reduced productivity, but which were still suitable for use in local farming systems; strongly degraded 
soils as soils in which productivity is virtually lost and are not suitable for agricultural use without major restoration investments; and extremely degraded soils as 'human-induced wasteland' beyond restoration.

5 Both livelihood strategies and development pathways may be studied at different scales, such as at community, household or individual level.

6 The empirical work of Pender and colleagues focuses on changes in income strategies and natural resource management, which are subsets of the more encompassing notion of livelihood strategies as defined by DFID (1999). Similar concepts have been introduced by other researchers. For example, Scoones and Wolmer (2002) refer to heterogeneous pathways of change in crop-livestock systems in different contexts of sub-Saharan Africa, including: (i) development of mixed crop-livestock integrated systems; (ii) integration of communal rangelands and individualized crop production; (iii) specialization and separation of extensive livestock and crop production; (iv) separate intensification of crop and livestock production; and (v) abandonment of cattle production with intensification of small-farm garden agriculture and off-farm income. Dixon et al. (2001) refer to household poverty reduction strategies, including agricultural intensification, diversification, increased farm size and increased off-farm income. While there are differences among these concepts, they are similar in emphasizing dynamic processes of change in livelihoods.

7 Local projects rely on direct and indirect incentives (input subsidies, free seed provision, food-for-work programmes, etc.) to stimulate adoption, but maintenance of SWC structures is easily abandoned once these facilities are phased out (Feder ef al., 1985).

8 Such schemes, already used in Mexico and piloted in India, index contracts to measurements at local weather stations rather than individual experiences, and can be provided by the private sector without the need for subsidies.

9 Early interventions of this kind in the Isiolo district Kenya proved to be rather effective for maintaining purchasing power of pastoralists and stabilizing the local livestock sector. After drought, credit for new foundation stocks is provided to farmers in order to re-establish their activities (De Haan et al., 2001).

10 Areas can be defined according to place and space characteristics. Place refers to climate and soil conditions that limit returns to agricultural production and render yields highly uncertain, especially under conditions of high population density. Space refers mainly to distance to markets and services, occasioning high transaction costs. In both settings, barriers to migration - either because moving is costly and risky or because people cannot move due to local patronage systems - could easily lead to spatial poverty traps. Thin land markets and harriers to borrowing further reduce the prospects for escaping from poverty.

11 This subsection draws heavily from Pender et al. (2006b).

12 For example, rapid adoption of improved maize varieties and fertilizer in Ethiopia in the early 2000 s led to a dramatic fall in maize prices and farmers' disillusionment with the technology.

\section{References}

Abegaz, A. (2005) Farm management in mixed crop-livestock systems in the Northern Highlands of Ethiopia. Tropical Resource Management Papers No. 70, PhD dissertation, Wageningen University and Research Center, The Netherlands.

Afifi-Affat, K.A. (1998) Heifer in trust: a model for sustainable livestock development? World Animal Review 91, 13-20. 
Allison, E.H. and Ellis, F. (2001) The livelihoods approach and management of smallscale fisheries. Marine Policy 25, 377-388.

Ashley, C, and Carney, D. (1999) Sustainable Livelihoods: Lessons from Early Experience. Department for International Development, London.

Baijukya, F.P. and De Steenhuijsen Piters, B. (1998) Nutrient balances and their consequences in the banana-based land use systems of Bukoba District, northwest Tanzania. Agriculture Ecosystems and Environment 71, 149-160.

Baker, J.L. and Grosh, M.E. (1994) Poverty reduction through geographical targeting: how well does it work? World Development 22, 983-995.

Barbier, B. and Bergeron, G. (2001) Natural Resource Management in the Hillsides of Honduras: Bioeconomic Modeling at the Microwatershed Level. Research Report No. 123, International Food Policy Research Institute, Washington, DC.

Barrett, C.B. and Maxwell, D.G. (2005) Food Aid after Fifty Years: Recasting its Role. Routledge, London.

Barrett, C.B., Reardon, T. and Webb, P. (2001) Non-income diversification and household livelihood strategies in rural Africa: concepts, dynamics and policy implications. Food Policy 26, 315-331.

Barrett, C.B., Place. F. and Aboud, A. (2002) The challenges of stimulating adoption of improved natural resource management practices in African agriculture. In: Barrett, C.B., Place, F. and Aboud, A.A. (eds) Natural Resources Management in African Agriculture. ICRAF and CABI, Nairobi, Kenya.

Bassett, T.J. and Crummey, D. (2003) Contested images, contested realities: environment and society in African savannas. In: Bassett, 'T.J. and Crummey, D. (eds) African Savannas: Global Narratives and Local Knowledge of Environmental Change. James Currey, Oxford.

Bationo, A., Lompo, F. and Koala, S. (1998) Research on nutrient flows and balances in West Africa: state-of-the-art. Agriculture Ecosystems and Environment 71, 19-35.

Bekunda, M.A., Bationo, A. and Ssali, H. (1997) Soil fertility management in Africa: a review of selected research trials. In: Buresh, R.J., Sanchez, P.A. and Calhoun, F. (eds) Replenishing Soil Fertility in Africa. Soil Science Society of America, Madison, Wisconsin.

Benin, S. (2006) Policies and programs affecting land management practices, input use and productivity in the highlands of Amhara region, Ethiopia. In: Pender, J., Place, F., and Ehui, S. (eds) Strategies for Sustainable Land Management in the East African Highlands. IFPRI, Washington, DC.

Berckmoes, W.M.L., De Jager, E.J. and Kone, Y. (1990) L'Intensification Agricole au Mali-Sud: Souhait ou Réalité? Bulletin no. 318, Royal Tropical Institute, Amsterdam.

Bigman. D. and Fofack, H. (2000) Geographical Targeting for Poverty Alleviation: Methodology and Applications. World Bank, Washington, DC.

Bird, K., Hulme, B., Moore, K. and Sheperd, A. (2002) Chronic Poverty and Remote Rural Areas. CPRC Working Paper No. 13, Chronic Poverty Research Centre, Birmingham and Manchester, UK.

Bishop, J. (1995) The Economics of Soil Degradation: an Illustration of the Change in Productivity Approach to Valuation in Mali and Malawi. LEEC paper DP 95-02, International Institute for Environment and Development, London.

Bishop, J. and Allen, J. (1989) The On-site Costs of Soil Erosion in Mali. Environment Working Paper No. 21, Environment Department. The World Bank, Washington, DC.

Bojö, J. (1991) The Economics of Land Degradation: Theory and Applications to Lesotho. The Stockholm School of Economics, Stockholm.

Bojö, J. (1996) The costs of land degradation in Sub-Saharan Africa. Ecological Economics $16,161-173$. 
Bojö, J. and Cassells, D. (1995) Land Degradation and Rehabilitation in Ethiopia: a Reassessment. AFTES Working Paper No. 17, World Bank, Washington, DC.

Boxall, R.A. (2001) Postharvest losses to insects: a world overview. International Biodeterioration and Biodegradation 48, 137-152.

Bruce, J. and Migot-Adholla, S. (eds) (1993) Searching for Land Tenure Security in Africa. Kendall/Hunt Publishing Company, Dubuque, lowa.

Brummett, R.E. (2002) Realizing the potential of integrated aquaculture: evidence from Malawi. In: Uphoff, N. (ed.) Agroecological Innovations: Increasing Food Production with Participatory Development. Earthscan, London.

Bunch, R. (2002) Increasing productivity through agro-ecological approaches in Central America: experiences from hillside agriculture. In: Uphoff, N. (ed.) Agro-ecological Innovations: Increasing Food Production with Participatory Development. Earthscan, London.

CGIAR/TAC (2000) CGIAR Research Priorities for Marginal Lands. Consultative Group on International Agricultural Research/Technical Advisory Committee, TAC Secretariat, Food and Agriculture Organization of the United Nations (FAO), Rome.

Chaves, B. and Riley, J. (2001) Determination of factors influencing integrated pest management adoption in coffee berry borer in Colombian farms. Agriculture, Ecosystems and Environment 87, 159-177.

Clay, D.C., Reardon, T. and Kangasniemi, J. (1998) Sustainable intensification in the highland tropics: Rwandan farmers' investments in land conservation and soil fertility. Economic Development and Cultural Change 46, 351-378.

Cleaver, K. and Schreiber, G. (1994) Reversing the Spiral: the Population Agriculture, and Environment Nexus in sub-Saharan Africa. World Bank, Washington, DC.

Cohen, M., Shepherd, K. and Walsh, M. (2005a) Empirical reformulation of the universal soil loss equation for erosion risk assessment in a tropical watershed. Geoderma 124, 235-252.

Cohen, M.J., Brown, M.T. and Shepherd, K.D. (2005b) Estimating the Environmental Costs of Soil Erosion at Multiple Scales in Kenya using Energy Synthesis. Mimeo, International Centre for Research in Agroforestry, Nairobi.

Convery, F. and Tutu, K. (1990) Evaluating the Costs of Environmental Degradation: Ghana-Applications of Economics in the Environmental Action Planning Process in Africa. University College Dublin, Environmental Institute, Dublin.

Crosson, P.R. (1995) Soil Erosion and its On-farm Productivity Consequences: What do we Know? Resources for the Future Discussion Paper 95-29, Resources for the Future, Washington, DC.

Cuesta, M.D. (1994) Economic Analysis of Soil Conservation Projects in Costa Rica. In: Lutz, E., Pagiola, S. and Reiche, C. (eds) Economic and Institutional Analyses of Soil Conservation Projects in Central America and the Caribbean. A CATIE-World Bank Project, World Bank Environment Paper 8, The World Bank, Washington, DC.

Dasgupta, S., Deichmann, U., Meisner, C. and Wheeler, D. (2003) The Poverty/ Environment Nexus in Cambodia and Lao People's Democratic Republic. World Bank Policy Research Working Paper 2960, World Bank, Washington, DC:

Deckers, J. (2002) A systems approach to target balanced nutrient management in soilscapes of Sub-Saharan Africa. In: Vanlauwe, B., Diels, J., Sanminga, N. and Merckx, R. (eds) Integrated Plant Nutrient Management in Sub-Saharan Africa: from Concept to Practice. CAB International, Wallingford, UK.

Defoer, T., De Groote, H., Hilhorst, T., Kanté, S. and Budelman, A. (1998) Participatory action research and quantitative analysis for nutrient management in southern Mali. Agriculture Ecosystems and Environment 71. 
De Graaff, J. (1996) The Price of Soil Erosion. An Economic Evaluation of Soil Conservation and Watershed Development. Mansholt Studies No. 3, Wageningen Agricultural University, Wageningen, The Netherlands.

De Haan, A. and Lipton, M. (1998) Poverty in Emerging Asia: progress, setbacks, and logjams. Asian Development Review 16, 2.

De Haan, C., Van Veen, T.-S., Brandenburg, B., Gauthier, J., Le Gall, F., Mearns, R. and Simeon, M. (2001) Livestock Development: Implications for Rural Poverty, the Environment and Global Food Security. World Bank, Washington, DC.

De Jager, A., Kariuki, I., Matiri, F.M., Odendo, M. and Wanyama, J.M. (1998) Monitoring nutrient flows and economic performance African farming systems (NUTMON). IV. Linking nutrient balances and economic performance in three districts in Kenya. Agriculture Ecosystems and Environment 71, 81-92.

De Jager, A., Onduru, D. and Walaga, C. (2004) Facilitated learning in soil fertility management: assessing potentials of low-external-input technologies in East African farming systems. Agricultural Systems 79, 205-223.

Delgado, C., Rosegrant, M., Steinfeld, H., Ehui, S. and Courbios, C. (1999) Livestock to 2020: The Next Food Revolution. Food, Agriculture and Environment Discussion Paper No. 28, International Food Policy Research Institute, Washington, DC.

Dercon, S. (1998) Wealth, risk and activity choice: cattle in Western Tanzania. Journal of Development Economics 55, 1-42.

DFID (1999) Sustainable Livelihoods Guidance Sheets. Department for International Development, UK (http://www.livelihoods.org).

Dietz, T., Verhagen, J. and Ruben, R. (eds) (2004) Impact of Climate Change on Drylands, with a Focus on West Africa. Kluwer Academic Publishers, Dordrecht, The Netherlands/Boston, Massachusetts.

Diop (2001) Management of organic inputs to increase food production in Senegal. In: Uphoff, N. (ed.) Agroecological Innovations: Increasing Food Production with Participatory Development. Earthscan, London.

Dixon, J., Gulliver, A. and Gibbon, D. (2001) Farming Systems and Poverty: Improving Farmers 'Livelihoods in a Changing World. FAO, Rome and World Bank, Washington, DC:

Dixon, R.K. (1995) Agroforestry systems: sources of sink or greenhouse gasses? Agroforestry Systems 31, 99-116.

Dregne, H.E. (1990) Erosion and soil productivity in Africa. Journal of Soil and Water Conservation 45, 432-436.

Dregne, H.E. and Chou, N.T. (1992) Global desertification dimensions and costs. In: Dregne, H.E. (ed.) Degradation and Restoration of Arid Lands. Texas Tech University, Lubbock, Texas.

Eaton, D. (1996) The Economics of Soil Erosion: a Model of Farm Decision Making. Discussion paper 96-01, Environmental Economics Programme, International Institute for Environment and Development, London.

Ehui, S., Hertel, T. and Preckel, P. (1990) Forest resource depletion, soil dynamics, and agricultural productivity in the tropics. Journal of Environmental Economics and Manogement 18, 136-154.

Elbers, C., Fujii, 'T., Lanjouw, P., Ozler, B. and Yin, W. (2004) Poverty Alleviation through Geographic Targeting: how much does Aggregation Help? Mimeo, Vrije Universiteit, Amsterdam.

Elias, E., Morse, S. and Belshaw, D.G.R. (1998) The nitrogen and phosphorus balances of some Kindo Koisha farms in southern Ethiopia. Agriculture Ecosystems and Environment 71, 93-113. 
Ellis, F. (2000) Rural Livelihoods and Diversity in Developing Countries. Oxford University Press, Oxford, UK.

Ellis, F. and Bahiigwa, G. (2003) Livelihoods and rural poverty reduction in Uganda. World Development 31, 997-1013.

Ellis, F. and Mdoe, N. (2003) Livelihoods and rural poverty reduction in Tanzania. World Development 31, 1367-1384.

Ellis, F., Kutengule, M. and Nyasulu, A. (2003) Livelihoods and rural poverty reduction in Malawi. World Development 31, 1495-1510.

Enters, T. (1998) Method for economic assessment of the on- and off-site impacts of soil erosion. Issues in Sustainable Land Management 2.

Erenstein, O.C.A. (1999) The economics of soil conservation in developing countries: the case study of crop residue mulching. PhD Thesis, Wageningen University. Wageningen, The Netherlands.

Escobal, J. (2005) The role of public infrastructure in market development in rural Peru. PhD Thesis. Wageningen University, Wageningen, The Netherlands.

Escobal, J. and Valdivia, M. (2005) Characterizing Diversity in the Peruvian Rural Sierra: a First Trial towards a Typology. Mimeo GRADE, Lima, Peru and International Food Policy Research Institute, Washington, DC.

Fafchamps, M., Udry, C. and Czukas, K. (1998) Drought and savings in West Africa: are livestock a buffer stock? Journal of Development Economics 55, 273-305.

Fairhead, J. and Leach, M. (1996) Misreading the African Landscape: Society and Ecology in a Forest-Savanna Mosaic. Cambridge University Press, Cambridge, UK.

Fairhead, J. and Scoones, I. (2005) Local knowledge and the social shaping of soil investments: critical perspectives on the assessment of soil degradation in Africa. Land Use Policy 22, 33-42.

Fan, S. and Chan-Kang, C. (2004) Returns to investment in less-favored areas in developing countries: a synthesis of evidence and implications for Africa. Food Policy 29. 431-444.

Fan, S. and Hazell, P. (2001) Returns to public investments in the less-favored areas of India and China. American Journal of Agricultural Economics 85, 1217-1222.

Fan, S., Hazell, P. and Haque, T. (2000) Targeting public investments by agro-ecological zone to achieve growth and poverty alleviation goals in rural India. Food Policy 25, 411-428.

Fan, S., Zhang, L. and Zhang, X. (2002) Growth, Inequality. and Poverty in Rural China. Research Report 125, International Food Policy Research Institute, Washington, DC.

Fan, S., Thorat, S. and Rao, N. (2003) Investment, Subsidies, and Pro-poor Grouth in Rural India. Draft report submitted to DFID. International Food Policy Research Institute, Washington, DC.

FAO (1986) Highlands Reclamation Study: Ethiopia. Final Report, vols I and II. Food and Agriculture Organization of the United Nations, Rome.

FAO (1997) State of the World's Forest. Food and Agriculture Organization of the United Nations, Rome.

FAO (2002) Food Insecurity, Poverty, and Agriculture: a Concept Paper. Food and Agriculture Organization of the United Nations, Rome.

FAO/World Bank (2001) Farming Systems and Poverty: Improving Farmers' Livelihoods in a Changing World. FAO, Rome and World Bank, Washington, JC.

Feder, G., Just, R.E. and Zilberman, D. (1985) Adoption of agricultural innovations in developing countries: a survey. Economic Development and Cultural Change 33 . $255-298$.

Folmer, E.C.R., Geurts, P.M.H. and Francisco, J.R. (1998) Assessment of soil fertility depletion in Mozambique. Agriculture, Ecosystems and Environment 71, 159-167. 
Franzel, S. (1999) Socio-economic factors affecting the adoption potential of improved tree fallows in Africa. Agroforestry Systems 47, 305-321.

Gachimbi, L.N., De Jager, A., Van Keulen, H., Thuranira, E.G. and Nandwa, S.M. (2002) Participatory Diagnosis of Soil Nutrient Depletion in Semi-arid Areas of Kenya. Managing Africa's Soils No. 26, International Institute for Environment and Development, London.

Gachimbi, L.N., Van Keulen, H., Thuranira, E.G., Karuku, A.M., De Jager, A., Nguluu, S., Ikombo, B.M., Kinama, J.M., Itabari, J.K. and Nandwa, S.M. (2005) Nutrient balances at farm level in Machakos (Kenya), using a participatory nutrient monitoring (NUTMON) approach. Land Use Policy 22, 13-22.

Garrity, D. (2002) Increasing the scope for food production on sloping lands in Asia: contour farming with natural vegetation strips in the Philippines. In: Uphoff, N. (ed.) Agro-ecological Innovations: Increasing Food Production with Participatory Development. Earthscan, London.

Gitari, J.N., Matiri, F.M., Kariuki, I.W., Muriithi, C.W. and Gachanja, S.P. (1999) Nutrient and cash flow monitoring in farming systems on the eastern slopes of Mount Kenya. In: Smaling, E.M.A., Oenema, O. and Fresco, L.O. (eds) Nutrient Disequilibria in Agro-ecosystems. CAB International, Wallingford, UK.

Glover, D. (1990) Contract farming and outgrower schemes in East and Southern Africa. Journal of Agricultural Economics 41, 303-315.

Goma, H.C., Rahim, K., Nangendo, G., Riley, J. and Stein, A. (2001) Participatory studies for agro-ecosystem evaluation. Agriculture, Ecosystems and Environment 87, 179-190.

Grohs, F. (1994) Economics of Soil Degradation. Erosion, and Conservation: a Case Study of Zimbabwe. Arbiten zur Agrarwirtschaft in Entwicklungsländern, Wissenschaftsverlag Vauk KG, Kiel, Germany.

Hassane, A., Martin, P. and Reij, C. (2000) Water Harvesting. Land Rehabilitation and Household Food Security in Niger. VU/IFAD, Amsterdam/Rome.

Hayami, Y. and Otsuka, K. (1993) The Economics of Contract Choice: an Agrarion Perspective. Clarendon Press, Oxford, UK.

Hazell, P. (1999) Public policy and drought management in agropastoral systems. In: McCarthy, N., Swallow, B., Kirk, M. and Hazell, P. (eds) Property Rights, Risk and Livestock Development in Africa. International Food Policy Research Institute, Washington, DC ind International Livestock Research Institute, Nairobi.

Hazell, P., Ruben, R., Kuyvenhoven, A. and Jansen, H. (2006) Investing in Poor People in Less-favored Areas. International Food Policy Research Institute (IFPRI) and WUR research report for IFAD, Rome.

Hengsdijk, H. (2002) Formalising agro-ecological knowledge for future-oriented land use studies. Doctoral thesis. Wageningen University, Wageningen, The Netherlands.

Hoben, A. (1995) Paradigms and politics: the cultural construction of environmental policy in Ethiopia. World Development 23, 1007-1021.

Hoffmann, I., Gerling, D., Kyiogwom, U.B. and Mané-Bielfeldt, A. (2001) Farmers' management strategies to maintain soil fertility in remote areas in northwest Nigeria. Agriculture, Ecosystems and Environment 86, 263-275.

Holden, S., Shiferaw. B. and Pender, J. (2004) Non-farm income, household welfare, and sustainable land management in a less-favoured area in the Ethiopian highlands. Food Policy 29, 369-392.

Holden, S., Shiferaw, B. and Pender, J. (2005) Policy Analysis for Sustainable Land Management and Food Security: a Bio-economic Model with Market Imperfections. International Food Policy Research Institute Research Report No. 140, Washington, DC: 
Huang, J. and Rozelle, S. (1994) Environmental stress and grain yields in China. American Journal of Agricultural Economics 77, 246-256.

Huang, J. and Rozelle, S. (1996) Technological change: rediscovering the engine of productivity growth in China's rural economy. Journal of Development Economics 49, $337-369$.

Hurni, H. (1988) Degradation and conservation of the resources in the Ethiopian highlands. Mountain Research and Development 8, 123-130.

ICRAF (1999) Sahelian Programme: Caring for the Sahel through Agroforestry. Concept Note. International Center for Research in Agroforestry, Nairobi.

IFAD (1999) India: Country Strategic Opportunities Paper. Report No. 896-IN, IFAD, Rome.

IFAD (2002) Assessment of Rural Poverty: Asia and the Pacific. International Fund for Agricultural Development, Asia and the Pacific Division, Project Management Department. Rome.

Jaffee, S. (1995) The many faces of success: the development of Kenyan horticultural exports. In: Jaffee, S. and Morton, J. (eds) Marketing Africa's High-value Foods: Comparative Experiences of an Emergent Private Sector. The World Bank. Washington, DC.

Jagger, P. and Pender, J. (2006) Impacts of programs and organizations on the adoption of sustainable land management technologies in Uganda. In: Pender, J., Place, F. and Ehui, S. (eds) Strategies for Sustainable Land Management in the East African Highlands. IFPRI, Washington, DC.

Jansen, H.G.P., Pender, J., Damon, A. and Schipper, R. (2006) Rural Development Policies and Sustainable Land Use in the Hillside Areas of Honduras: a Quantitative Livelihoods Approach. Research Report No. 144, International Food Policy Research Institute, Washington, DC.

Jayne, T.S., Yamano, T., Weber, M.T., Tschirley, D., Benfica, R., Chapoto, A. and Zulu, B. (2003) Smallholder income and land distribution in Africa: implications for poverty reduction strategies. Food Policy 28, 253-275.

Juo, A.S.R. and Kang, B.T. (1989) Nutrient effects of modification of shifting cultivation in West Africa. In: Proctor, J. (ed.) Mineral Nutrients in Tropical Forest and Savanna Ecosystems. Blackwell, Oxford, UK.

Kam, S., Hossain, M., Bose, M. and Villano, L.S. (2005) Spatial patterns of rural poverty and their relationships with welfare influencing factors in Bangladesh. Food Policy $30(5 / 6), 551-567$.

Keeley, J. and Scoones, I. (2003) Understanding Environmental Policy Processes: Cases from Africa. Earthscan, London.

Kelley, T.G. and Byerlee, D. (2003) Surviving on the Margin: Agricultural Research and Development Strategies for Poverty Reduction in Marginal Areas. Mimeo CGIAR, Science Council Secretariat, Rome and World Bank, Washington, DC.

Kelley, T.C. and Parthasarathy Rao, P. (1995) Marginal environments and the poor: evidence from India, Economic and Political Weekly 30, 2494-2495.

Kerr, J., Pangare, G. and Pangare, V.L. (2001) The Role of Watershed Projects in Developing Rainfed Agriculture in India. Research Report, International Food Policy Research Institute, Washington, DC.

Key, N. and Runsten, D. (1999) Contract farming, smallholders and rural development in Latin America: the organization of agroprocessing firms and the scale of outgrower production. World Development 27, 381-401.

Knox, A., Meinzen-Dick, R. and Hazell, P. (2002) Property rights, collective action, and technologies for natural resource management: a conceptual framework. In: MeinzenDick, R., Knox, A., Place, F. and Swallow, B. (eds) Innovation in Natural Resource 
Management; the Role of Property Rights and Collective Action in Developing Countries. IFPRI, Johns Hopkins University Press, Baltimore, Maryland.

Koning, N. and Smaling, E. (2005) Environmental crisis or 'lie of the land'? The debate on soil degradation in Africa. Land Use Policy 22, 3-12.

Kruseman, G., Ruben, R. and Tesfay, G. (2006) Village stratification for policy analysis: multiple development domains in the Ethiopian highlands of Tigray. In: Pender, J., Place, F. and Ehui, S. (eds) Strategies for Sustainable Land Management in the East African Highlands. IFPRI, Washington, DC.

Kuyvenhoven, A. and Bigman, D. (2002) Technical standards in a liberalised agri-food system: institutional implications for developing countries. Tijdschrift voor Sociaalwetenschappelijk Onderzoek van de Landbouw 17, 51-62.

Kuyvenhoven, A., Becht, J.A. and Ruben, R. (1998) Financial and economic evaluation of phosphate rock use to enhance soil fertility in West Africa. In: Wossink, G.A.A., Van Kooten, G.C. and Peters, G.H. (eds) Economics of Agro-chemicals. Ashgate, Aldershot, UK, pp. 249-261.

Lal, R. (1995) Erosion-crop productivity relationships for soil of Africa. Soil Science Society of America Journal 59, 661-667.

Leach, M. and Mearns, R. (1996) Environmental change \& policy: challenging received wisdom in Africa. In: Leach, M. and Mearns, R. (eds) The Lie of the Land: Challenging Received Wisdom on the African Environment. The International African Institute in association with James Currey, London.

Leaky, R.R.B. and Tchoundjeu, Z. (2001) Diversification of tree crops: domestication of companion crops for poverty reduction and environmental services. Exploratory Agriculture 37, 270-296.

Lipton, M. (2005) The Family Farm in a Globalizing World: the Role of Crop Science in Alleviating Poverty. 2020 Discussion Paper No. 40, International Food Policy Research Institute, Washington, DC.

Lutz, E., Pagiola, S. and Reiche, C. (eds) (1994) Economic and Institutional Analyses of Soil Conservation Projects in Central America and the Caribbean. A CATIE-World Bank Project, World Bank Environment Paper 8, The World Bank, Washington, DC.

McCann, J.C. (1999) Green Land, Brow'n Land, Black Land: an environmental history of Africa, 1800-1990. James Currey, Oxford, UK.

McCarthy, N., Swallow, B., Kirk, M. and Hazell, P. (eds) (1999) Property Rights, Risk and Livestock Development in Africa. IFPRI, Washington, DC and ILRI, Nairobi.

McIntire, J. (1994) A review of the soil conservation sector in Mexico. In: Lutz, E., Pagiola, S. and Reiche, C. (eds) Economic and Institutional Analyses of Soil Conservation Projects in Central America and the Caribbean. A CATIE-World Bank Project, World Bank Environment Paper 8, The World Bank, Washington, DC.

McIntyre, J., Bourzat, D. and Pingali, P. (1992) Crop-Livestock Interaction in Sub-Saharan Africa. World Bank, Washington, DC.

McKenzie, C. (1994) Degradation of arable land resources: policy options and considerations within the context of rural restructuring in South Africa. Paper prepared for the LAPC Workshop, Johannesburg, South Africa.

McNeely, J.A. (ed.) (2001) The Great Reshuffling: Human Dimensions of Invasive Alien Species. International Union for the Conservation of Nature, Gland, Switzerland.

MEA (2005) Millennium Ecosystem Assessment Synthesis Report.

Meinzen-Dick, R.S. (1997) Farmer participation in irrigation: 20 years of experience and lessons for the future. Irrigation and Drainage Systems 11, 103-118.

Minot, N. (2000) Generating disaggregated poverty maps: an application to Viet Nam. World Development 28, 319-331. 
Muchena, F.N., Onduru, D.D., Gachini, G.N. and De Jager, A. (2005) Turning the lides of soil degradation in Africa: capturing the reality and exploring opportunities. Land Use Policy 22, 23-32.

Mulder, 1. (2001) Soil degradation in Benin: farmers' perceptions and responses. Doctoral thesis, Thela Research series No. 240, Tinbergen Institute, Amsterdam.

Nelson, R., Cramb, R.A.. Manz, K.M. and Mamicpic, M.A. (1998) Bio-economic modelling of alternative forms of hedgerow intercropping in the Philippine uplands. Agroforestry Systems 30, 241-262.

Neupane, R. and Thapa, G.B. (2001) Impact of agroforestry intervention on soil fertility and farm income under the subsistence farming system of the middle hills, Nepal. Agriculture, Ecosystems and Environment 84, 157-167.

Niehof, A. (2004) The significance of diversification for rural livelihood systems. Food Policy 29, 321-338.

Nkonya, P., Pender, J., Jagger, P., Sserunkuuma. D., Kaizzi, C.K. and Ssali, H. (2004) Strategies for Sustainable Land Management and Poverty Reduction in Uganda. Research Report No. 133, International Food Policy Research Institute. Washington, DC.

Nkonya, E., Kaizzi, C.K. and Pender, J. (2005a) Determinants of nutrient balances in maize farming systems in eastern Uganda. Agricultural Systems 85, 155-182.

Nkonya, E., Pender, J., Kaizzi, C., Edward, K. and Mugarura, S. (2005b) Policy Options for Increasing Crop Productivity and Reducing Soil Nutrient Depletion and Poverty in Uganda. Environment and Production Terhnology Division Discussion Paper No. 134, International Food Policy Research Institute, Washington, DC.

Norse, D. and Saigal, R. (1992) National economic cost of soil erosion: the case of Zimbabwe. Paper prepared for the CIDIE Workshop on Environmental Management and Natural Resource Management in Developing Countries, 22-24 January, World Bank, Washington, DC.

Okumu, B.N., Jabbar, M.A., Colman, D. and Russell, N. (2002) A bio-economic: model of integrated crop-livestork farming systems: the case of the Ginchi watershed in Ethiopia. In: Barrett, C.B., Place, F. and Aboud, A.A. (eds) Natural Resources Management in African Agriculture: Understanding and Improving Current Practices. CAB International, Wallingford, UK.

Oldeman, L.R. (1998) Soil Degradation: a Threat to Food Security? Report 98/01. International Soil Reference and Information Centre, Wageningen, The Netherlands.

Oldeman, L.R., Hakkeling, R.T.A. and Sombroek, W.G. (1991) World Map of the Stafus of Human-induced Soil Degradation: an Explanatory Note. International Soil Reference and Information Centre, Wageningen, The Netherlands and United Nations Environment Programme, Nairobi.

Onduru, D.D., De Jager, A., Gachini, G.N. and Diop, J.-M. (2001) Exploring New'Pathways for Innovative Soil Fertility Management in Kenya. Managing Africa’s Soils No. 25. International Institute for Environment and Development. London.

Orr, A. and Jere, P. (1999) Identifying smallholder target groups for IPM in southern Malawi. International Journal of Pest Management 45, 179-187.

Otsuka, K. and Place, F. (2001) Land Tenure and Natural Resource Management: a Comparative Study of Agrarian Communities in Asia and Africa. The Johns Hopkins University Press, Baltimore, Maryland and IFPRI, Washington, DC.

Pagiola, S. (1993) Soil conservation and the sustainability of agricultural production. PhD dissertation, Stanford University, California.

Pagiola, S. and Dixon, J. (1997) Land Degradation Problems in El Salvador, Annex 7 - El Salvador. Rural Development Study Report No. 16253-ES, World Bank, Washington, DC. 
Pender, J. (1998) Population growth, agricultural intensification, induced innovation and natural resource sustainability: an application of neoclassical growth theory. Agricultural Economics 19, 99-112.

Pender, J. (2004) Development pathways for hillsides and highlands: some lessons from Central America and East Africa. Food Policy 29, 339-367.

Pender, J. and Gebremedhin, B. (2006) Land management, crop production and household income in the highlands of Tigray, northern Ethiopia. In: Pender, J., Place, F. and Ehui, S. (eds) Strategies for Sustainable Land Management in the East African Highlands. International Food Policy Research Institute, Washington, DC.

Pender, J. and Kerr, J. (1998) Determinants of farmers' indigenous soil and water conservation investments in India's semi-arid tropics. Agricultural Economics 19, 113-125.

Pender, J., Gebremedhin, B., Benin, S. and Ehui, S. (2001a) Strategies for sustainable development in the Ethiopian highlands. American Journal of Agricultural Economics 83, 1231-40.

Pender. J., Scherr, S.J. and Durón, G. (2001b) Pathways of development in the hillsides of Honduras: causes and implications for agricultural production, poverty, and sustainable resource use. In: Lee, D.R. and Barrett, C.B. (eds) Tradeoffs or Synergies? Agricultural Intensification. Economic Development and the Environment. CAB International, Wallingford, UK.

Pender, J., Gebremedhin, B., Benin, S. and Ehui, S. (2001c) Strategies for Sustainable Agricultural Development in the Ethiopian Highlands. Environment and Production Technology Discussion Paper No. 77, Environment and Production Technology Division, International Food Policy Research Institute, Washington, DC.

Pender, J., Jagger, P., Nkonya, E. and Sserunkuuma, D. (2001d) Development Pathways and Land Management in Uganda: Causes and Implications. Environment Production and Technology, Discussion Paper 85, International Food Policy Research Institute, Washington, DC.

Pender, J., Scherr, S. and Durón, G. (2001e) Pathways of development in the hillside areas of Honduras: causes and implications for agricultural production, poverty and sustainable resource use. In: Lee, D.R. and Barrett, C.B. (eds) Tradeoffs or Synergies? Agricultural Intensification, Development and the Environment. CAB International, Wallingford, UK.

Pender, J., Jagger, P., Nkonya, E. and Sserunkuuma, D. (2004) Development pathways and land management in Uganda. World Development 32, 767-792.

Pender, J., Ehui, S. and Place, F. (2006a) Conceptual framework and hypotheses. In: Pender, J., Place, F. and Ehui, S. (eds) Strategies for Sustainable Land Management in the East African Highlands. International Food Policy Research Institute, Washington, DC.

Pender, J., Place, F. and Ehui, S. (2006b) Strategies for sustainable land management in the East African highlands: conclusions and implications. In: Pender, J., Place, F. and Ehui, S. (eds) Strategies for Sustainable Land Management in the East African Highlands. International Food Policy Research Institute, Washington, DC.

Pingali, P.L. and Rosegrant, M. (2001) Intensive food systems in Asia: can the degradation problems be reversed? In: Lee, D.R. and Barrett, C.B. (eds) Tradeoffs or Synergies? Agricultural Intensification, Economic Development and Environment. CABI Publishing, Wallingford, UK, pp. 383-397.

Place, F., Kristjanson, P., Staal, S., Kruska, R., DeWolff, T., Zomer, R. and Njuguna, E.C. (2006a) Development pathways in medium to high-potential Kenya: a meso-level analysis of agricultural patterns and determinants. In: Pender, J., Place, F. and Ehui, S. (eds) Strategies for Sustainable Land Management in the East African Highlands. International Food Policy Research Institute, Washington, DC. 
Place, F., Njuki, J., Murithi, F. and Mugo, F. (2006b) Agricultural enterprise and land management in the highlands of Kenya. In: Pender, J., Place, F. and Ehui, S. (eds) Strategies for Sustainable Land Management in the East African Highlands. International Food Policy Research Institute, Washington, DC.

Ramadhani, T., Otsyina, R. and Franzel, S. (2002) Improving household incomes and reducing deforestation using rotational woodlots in Tabora district, Tanzania. Agriculture, Ecosystems and Environment 89, 229-239.

Ravallion, M. and Jalan, J. (1996) Growth differences due to spatial externalities. Economic Letters 53, 227-232.

Reardon, T. (1995) Sustainability issues for agricultural research strategies in the semiarid tropics: focus on the Sahel. Agricultural Systems 48, 345-360.

Reardon, T. (1997) Using evidence of household income diversification to inform study of the rural nonfarm labor market in Africa. World Development 25, 735-748.

Reardon, T., Delgado, C. and Matlon, P. (1992) Determinants and effects of income diversification amongst farm households in Burkina Faso. Journal of Development Studies 28, 264-296.

Reardon, T., Berdegué, J. and Escobar, G. (2001) Rural nonfarm employment and incomes in Latin America: overview and policy implications. World Development 29, 395-409.

Reij, C. and Steeds, D. (2003) Success Stories in African Drylands: Supporting Advocates and Assessing Sceptics. Paper commissioned by Global Mechanisms of the Convention to Combat Desertification, Centre for International Cooperation (CIS-VU), Amsterdam.

Reij, C., Scoones, I. and Toulmin, C. (1996) Sustaining the Soil: Indigenous Soil and Water Conservation in Africa. Earthscan, London.

Renkow, M. (1993) Differential technology adoption and income distribution in Pakistan: implications for research resource allocation. American Journal of Agricultural Economics 75, 33-43.

Renkow, M. (2000) Poverty, productivity and production environment: a review of the evidence. Food Policy 25, 463-478.

Rosegrant, M.W. and Perez, N.D. (1997) Water Resources Development in Africa: a Review and Synthesis of Issues, Potentials, and Strategies for the Future. Environment and Production Technology, Discussion Paper 28, International Food Policy Research Institute, Washington, DC.

Ruben, R. and Pender, J. (2004) Rural diversity and heterogeneity in less-favoured areas: the quest for policy targeting. Food Policy 29, 303-320.

Kuben, R., Kruseman, G., Hengsdijk, H. and Kuyvenhoven, A. (1996) The impact of agrarian policies on sustainable land use. In: Teng, P.S., Kropff, M.J., Ten Berge, H.F.M., Dent, J.B., Lansigan, F.P. and Van Laar, H.H. (eds) Applications of systems approaches at the farm and regional levels. Proceedings of the 2nd Symposium on System Approaches for Agricultural Development, Kluwer, Dordrecht, The Netherlands, pp. 65-82.

Ruben, R., Kruseman, G. and Kuyvenhoven, A. (2006) Strategies for sustainable intensification in East African highlands: labour use and input efficiency. Agricultural Economics 34, 167-181.

Ruben, R., Kuyvenhoven, A., Kruseman, G. (2001) Bio-economic models for eco-regional development: policy instruments for sustainable intensification. In: Lee, D.R. and Barrett, C.B. (eds) Tradeoffs or Synergies? Agricultural Intensification, Economic Development and the Environment in Developing Countries. CAB International, Wallingford, UK, pp. 115-134.

Ruben, R., Kuyvenhoven, A. and Hazell, P. (2003) Investing in poor people in poor lands. Contributed paper at the International Conference 'Staying Poor: Chronic Poverty and Development Policy', 7-9 April, Manchester, UK. 
Rukuni, M., Svendsen, M., Meinzen-Dick, R. and Makombe, G. (1994) Irrigation Performance in Zimbabwe. Faculty of Agriculture, University of Zimbabwe, Harare.

Ryan, J.G. and Spencer, D.S.C. (2001) Future Challenges and Opportunities for Agricultural $R \& D$ in the Semi-arid Tropics. International Crops Research Institute for the Semi-arid Tropics, Patancheru, Andhra Pradesh, India.

Sanchez, P.A. and Jama, B.A. (2002) Soil fertility replenishment takes off in east and southern Africa. In: Vanlauwe, B., Diels, J., Sanginga, N. and Merckx, R. (2002) Integrated Plant Nutrient Management in Sub-Saharan Africa: from Concept to Practice. CAB International, Wallingford, UK with IITA, pp. 23-45.

Scherr, S.J. (1999a) Soil Degradation: a Threat to Developing Country Food Security by 2020? Food, Agriculture and Environment Discussion Paper 27, International Food Policy Research Institute, Washington, DC.

Scherr, S.J. (1999b) Poverty-Environment Interactions in Agriculture: Key Factors and Policy Implications. Poverty Environment Initiative Paper No. 3, UNDP/EC, Washington, DC:

Scoones, I. and Toulmin, C. (1999) Policies for Soil Fertility Management in Africa. IIED/IDS, London and Brighton, UK, for DFID.

Scoones, I. and Wolmer, W. (2002) Pathways of change: crop-livestock integration in Africa. In: Scoones, I. and Wolmer, W. (eds) Pathways of Change in Africa: Crops Livestock and Livelihoods in Mali, Ethiopia and Zimbabwe. James Curry Ltd., Oxford, UK.

Sehgal, J. and Abrol, I.P. (1994) Soil Degradation in India: Status and Impact. Oxford University Press and IBH, New Delhi, India.

Shepherd, K.D. and Soule, M.J. (1998) Soil fertility management in West Kenya: dynamic simulation of productivity, profitability and sustainability at different resource endowment levels. Agriculture Ecosystems and Environment 71, 131-145.

Shiferaw, B. and Holden, S. (1999) Soil erosion and smallholders' conservation decisions in the highlands of Ethiopia. World Development 27, 739-752.

Skees, J., Hazell, P. and Miranda, M. (1999) New Approaches to Crop Yield Insurance in Developing Countries. EPTD Discussion Paper No. 55, International Food Policy Research Institute, Washington, DC.

Smaling, E.M.A., Nandwa, S.M. and Janssen, B.H. (1997) Soil fertility in Africa is at stake. In: Buresh, R.J., Sanchez, P.A. and Calhoun, F. (eds) Replenishing Soil Fertility in Africa. Soil Science Society of America and American Society of Agronomy, SSSA Spec. Publ. 51. SSA, Madison, Wisconsin, pp. 151-192.

Solórzano, R., De Camino, R. and Woodward, R. (1991) Accounts Overdue: Natural Resource Depreciation in Costa Rica. World Resources Institute, Washington, DC.

Sonneveld, B.C.J.S. (2002) Land under pressure: the impact of water erosion on food production in Ethiopia. PhD dissertation. Shaker Publishing, The Netherlands.

Ssali, H. (2003) Soil organic matter and its relationship to soil fertility changes in Uganda. In: Benin, S., Pender, J. and Ehui. S. (eds) Policies for Sustainable Land Management in the East African highlands. Summary of papers and proceedings of the conference held at the United Nations Economic Commission for Africa, Addis Ababa, Ethiopia, 24-26 April. Environment and Production Technology Division Workshop Summary Paper No. 13, International Food Policy Research Institute, Washington, DC.

Staal, S.J. (1995) Periurban dairying and public policy in Ethiopia and Kenya: a comparative economic and institutional analysis. PhD dissertation, Department of Food and Resource Economics, University of Florida, Gainesville, Florida.

Staal, S.J., Baltenweck, I., Waithaka, M.M., deWolff, T. and Njoroge, L. (2002) Location and uptake: integrated household and GIS analysis of technology adoption and land use, with application to smallholder dairy farms in Kenya. Agricultural Economics $27,295-315$. 
Stocking, M. (1986) The Cost of Soil Erosion in Zimbabwe in Terms of the Loss of Three Major Nutrients. Consultant's Working Paper No. 3, Soil Conservation Programme, Land and Water Development Division, AGLS, FAO, Rome.

Stocking, M. (1996) Soil erosion: breaking new ground. In: Leach, M. and Mearns, R. (eds) The Lie of the Land: Challenging Received Wisdom on the African Environment. The International African Institute in association with James Currey, London.

Stoorvogel, J.J., Smaling, E.M.A. and Janssen, B.H. (1993) Calculating soil nutrient balances at different scales. Fertilizer Research 35, 227-235.

Stroosnijder, L. and Van Rheenen, T. (2001) Agro-silvo-pastoral Land Use in Sahelian Villages. Advances in Geology 33, Catena Verlag, Reiskirchen, Germany.

Sutcliffe, J.P. (1993) Economic Assessment of Land Degradation in the Ethiopian highlands: a Case Study. National Conservation Strategy Secretariat, Ministry of Planning and Economic Development, Transitional Government of Ethiopia, Addis Ababa.

Swift, M.J., Seward, P.D., Frost, P.G.H., Qureshi, J.N. and Muchena, F.N. (1994) Long-term experiments in Africa: developing a database for sustainable land use under global change. In: Leigh, F.A. and Johnston, A.E. (eds) Long-term Experiments in Agricultural and Ecological Sciences. CAB International, Wallingford, UK.

Swinkels, R. and Franzel, S. (1997) Adoption potential of hedgerow intercropping systems in the highlands of western Kenya. Part II. Economic; and farmers evaluation. Experimental Agriculture 33, 211-223.

Swinkels, R. and Turk, C. (2004) Poverty and remote areas: evidence from new data and questions for the future. Background paper for the PAC Conference, Hanoi, Vietnam, 24-26 November, World Bank, Vietnam.

Swinton, S.M. and Williams, M.B. (1998) Assessing the Economic Impact of Integrated Pest Management: Lessons from the Past, Direction for the Future. Staff Paper No. 9812, Michigan State University, East Lansing, Michigan.

TAC (2001) CGIAR Research Priorities for Marginal Lands. SDR/TAC: IAR/99/12, Technical Advisory Committee of the CGIAR, Washington, DC.

Tanner, J.C., Holden, S.J., Owen, E., Winugroho, M. and Gill, M. (2001) Livestock sustaining intensive smallholder crop production through traditional feeding practices for generating high quality manure-compost in upland Java. Agriculture. Ecosystems and Environment 84, 21-30.

Tiffen, M., Mortimore, M. and Gichuki, F. (1994) More People - Less Erosion: Environmental Recovery in Kenya. Wiley and Sons, London.

UBOS (2003) Uganda National Household Survey 2002/2003. Report on the socioeconomic survey, Uganda Bureau of Statistics, Entebbe, Uganda.

Udry, C. (1990) Credit markets in Northern Nigeria: credit as insurance in a rural economy. World Bank Economic Review' 4, 251-270.

Umali, D., Feder, G. and De Haan, C. (1992) The Balance between Public and Private Sector Activity in the Delivery of Livestock Services. World Bank Discussion Paper No. 163, World Bank, Washington, DC.

UNDP (1997) Human Development Report 1997. United Nations Development Programme, Oxford University Press, New York.

Van den Bosch, H., Gitari, J.N., Ogaro, V.N., Maobe, S. and Vlaming, J. (1998) Monitoring nutrient flows and economic performance in African farming systems (NUTMON). Monitoring nutrient flows and balances in three districts in Kenya. Agriculture. Ecosystems and Environment 71, 63-80.

Van der Pol, F. (1992) Soil Mining: an Unseen Contributor to Farm Income in Southern Mali. Bulletin 325, Royal Tropical Institute, Amsterdam.

Van der Walle, D. and Gunewardena, D. (2001) Sources of ethnic inequality in Vietnam. Journal of Development Economics 65. 177-207. 
Vanlauwe, B., Diels, J., Sanginga, N. and Merckx, R. (2002) Integrated Plant Nutrient Management in Sub-Saharan Africa: From Concept to Practice. CAB International, Wallingford, UK with IITA.

Van Lynden, G. and Oldeman, L.R. (1997) Soil Degradation in South and Southeast Asia. International Soil Reference and Information Centre, Wageningen, The Netherlands.

Vitale, J.D. and Sanders, J.H. (2002) Demand-driven Technological Change and the Traditional Cereals in Sub-Saharan Africa: The Malian Case. Discussion Paper, Purdue University. West Lafayette, Indiana.

Vlek, P.L.G. (1990) The role of fertilizers in sustaining agriculture in sub-Saharan Africa. Fertiliser Research 26, 327-339.

Walker, T., Swinton, S., Hijmans, R., Quiroz, R., Valdivia, R., Holle, M., León-Velarde, C. and Posner, J. (2000) 'Technologies for the tropical Andes, Brief 3. In: Pender, J. and Hazell, P. (eds) Promoting Sustainable Development in Less-favored Areas. 2020 Vision Foc:us 4, International Food Policy Research Institute, Washington, DC.

Wiersum, K.F. (1997) From natural forest to tree crops, co-domestication of forests and tree species. Netherlands Journal of Agricultural Research 45, 425-438.

Williams, T.O., Hiernaux, P. and Fernandez-Riviera, S. (1999) Crop-livestock systems in Sub-Saharan Africa: determinants and intensification pathways. In: McCarthy, N., Swallow, B., Kirk, M. and Hazell, P. (eds) Property Rights, Risk and Livestock Development in Africa. International Food Policy Research Institute, Washington, DC and International Livestock Research Institute, Nairobi.

Woelcke, J. (2003) Bio-economics of sustainable land management in Uganda. In: Heidhues, F. and Von Braun, J. (eds) Series Developing Economics and Policy. Peter Lang, Frankfurt am Main, Germany, Berlin, Berne, Switzerland, Brussels, New York, Oxford.

Woelcke, J., Berger, 'T. and Park, S. (2006) Sustainable land management and technology adoption in eastern Uganda. In: Pender, J., Place, F. and Ehui, S. (eds) Strategies for Sustainable Land Management in the East African Highlands. International Food Policy Research Institute, Washington, DC.

Wood, S., Sebastian, K., Nachtergaele, F., Nielsen, D. and Dai. A. (1999) Spatial Aspects of the Design and Targeting of Agricultural Development Strategies. Environment and Production Technology, Discussion Paper No. 44, International Food Policy Research Institute, Washington, DC.

World Bank (1988) Madagascar - Environmental Action Plan, Vol. 1. In cooperation with USAID, Swiss Cooperation, UNESCO, UNDP and WWF, Washington, DC.

World Bank (1992) Malawi - Economic Report on Environmental Policy, Vols I and II. Report No. 9888-MAI. Washington, DC.

Wortmann, C..S. and Kaizzi, C.K. (1998) Nutrient balances and expected effects of alternative practices in farming systems of Uganda. Agriculture, Ecosystems and Environment 71, 115-130.

Yesuf, M., Mekonnen, A., Kassie, M. and Pender, J. (2005) Costs of Land Degradation in Ethiopia: a Critical Review of Past Studies. Mimeo Environmental Economics Policy Forum in Ethiopia. Addis Ababa and International Food Policy Research Institute, Washington, DC:

Zhang, X. (2004) Security is Like Oxygen: Evidence from Uganda. Development Strategy and Governance Division Discussion Paper No. 6, International Food Policy Research Institute, Washington, DC.

Zurayk, R., El-Awar, F., Hamadeh, F., 'Talhouk, S., Sayegh, C., Chehab, A.G. and Al Shab, K. (2001) Using indigenous knowledge in land use investigations: a participatory study on semi-arid mountainous region of Lebanon. Agriculture, Ecosystems and Environment 86, 247-262. 